\title{
Examining the salinity change in the upper Pacific Ocean during the Argo period
}

\author{
Guancheng $\mathrm{Li}^{1,2} \cdot$ Yuhong Zhang $^{3} \cdot$ Jingen $\mathrm{XiaO}^{4} \cdot \mathrm{Xiangzhou} \mathrm{Song}^{5} \cdot$ John Abraham $^{6} \cdot$ Lijing Cheng $^{1,2}$ (D) \\ Jiang Zhu ${ }^{1,2}$
}

Received: 14 January 2019 / Accepted: 24 July 2019 / Published online: 2 August 2019

(c) The Author(s) 2019

\begin{abstract}
During the Argo period, the Pacific Ocean as well as the global oceans became saltier in the upper-200 $\mathrm{m}$ from 2005 to 2015, with a significant spatial variability. Using Argo-based observations and the Estimating the Circulation and Climate of the Ocean (ECCO), a salinity budget analysis in the upper $200 \mathrm{~m}$ was conducted to investigate what controls the recent observed salinity change in the Pacific Ocean. The results showed that the increasing salinity since 2005 was mainly caused by a reduction of surface precipitation. The ocean advection dampened the surface freshwater anomalies and rebuilt regional salinity balance. Both precipitation and advection are closely associated with the sea surface wind anomalies, suggesting the wind-driven changes in the ocean salinity field. A further analysis using an ocean objective analysis product and model simulations in addition to ECCO suggests that the recent salinity pattern since 2005 are related to the Interdecadal Pacific Oscillation (IPO). This study also highlights the strong regulation of the ocean salinity change by natural decadal variability in the climate system.
\end{abstract}

Keywords Upper layer salinity changes · Precipitation · Ocean advection · Interdecadal Pacific Oscillation (IPO) · Surface winds

Electronic supplementary material The online version of this article (https://doi.org/10.1007/s00382-019-04912-z) contains supplementary material, which is available to authorized users.

Lijing Cheng

chenglij@mail.iap.ac.cn

1 International Center for Climate and Environment Sciences, Institute of Atmospheric Physics, Chinese Academy of Sciences, Beijing 100029, China

2 College of Earth and Planetary Sciences, University of Chinese Academy of Sciences, Beijing 100049, China

3 State Key Laboratory of Tropical Oceanography, South China Sea Institute of Oceanology, Chinese Academy of Sciences, Guangzhou 510301, Guangdong, China

4 School of Marine Science and Technology, Tianjin University, Tianjin 300072, China

5 College of Oceanography, Hohai University, Nanjing 210098, China

6 University of St. Thomas, St. Paul, MN 55105, USA

\section{Introduction}

Ocean salinity is a fundamental element for ocean stratification and large-scale ocean circulation (Roemmich et al. 1994; Lagerloef et al. 2010). Salinity (along with temperature and pressure) is important in defining the ocean state and offers key information for ocean geostrophic circulation (Fedorov et al. 2004), mixed layer depth (de Boyer et al. 2004), barrier layer thickness (Bosc et al. 2009), water mass formation (Rahmstorf 2003), and subduction processes (Fedorov et al. 2004; Yan et al. 2017).

The near-surface salinity changes are strongly determined by buoyancy forcing, namely the freshwater exchange at the air-sea interface (i.e. evaporation minus precipitation: $\mathrm{E}-\mathrm{P}$ ) and by ocean dynamics (Yu 2011). Discrepancies from poorly constrained and highly variable and episodic precipitation and surface fluxes make it very difficult to accurately quantify their trends related to anthropogenic climate change (Trenberth et al. 2005, 2011; Schanze et al. 2010). The salinity field behaves like a rain gauge (Schmitt 2008) by integrating the higher frequency and sporadic E-P fluxes (in concert with ocean 
advection and mixing), and thus its long-term changes can be used to reflect changes in E-P (Durack et al. 2012; Terray et al. 2012; Jan et al. 2018).

Previous studies indicate that the spatial pattern of longterm surface and subsurface salinity changes provide evidence for an intensified hydrological cycle. It is manifest as an enhancement of the existing mean salinity pattern: salty regions become saltier and fresh regions become fresher (Curry et al. 2003; Boyer et al. 2005; Hosoda et al. 2009; Durack and Wijffels 2010; Helm et al. 2010; Rhein et al. 2013; Skliris et al. 2014). The long-term change of ocean salinity is a key indicator of hydrological cycle change. For example, it shows a response of anthropogenic global warming (Hartmann et al. 2013; Rhein et al. 2013; Levang and Schmitt 2015). Physically, these trends are expected because of the increased capacity of the warmer atmosphere to hold more water vapor at a rate of approximate $7 \%$ following Clausius-Clapeyron $(\mathrm{C}-\mathrm{C})$ relationship (Held and Soden 2006). The multi-decadal subsurface salinity changes are likely due to a combination of two primary surface-forced processes associated with global warming. One is the warming-driven outcrop migration and the other is surfaceinduced salinity pattern amplification (Lago et al. 2016). The large-scale freshening of the Pacific intermediate water over the second half of the last century are found in the collected hydrographic sections, which can be attributed to an increasing freshwater input over the source region due to the anthropogenic global warming (Wong et al. 1999). Besides these long-term changes, the inter-annual and decadal-scale salinity changes are significant. The Sea surface salinity (SSS) anomalies in the Tropical Atlantic display a large interannual variation, which is mainly controlled by the interplay between atmospheric forcing (e.g. the displacement of the Intertropical Convergence Zone, ITCZ), and advection processes under the influence of river plumes (Ferry and Reverdin 2004; Awo et al. 2018). In the Pacific, the periodic shift of the Pacific Decadal Oscillation (PDO) in 1977/78 could explain the freshening of the North Pacific Intermediate Water (NPIW) in the recent decades. This significant decrease is associated with an increase in southward transport of Oyashio water, corresponding to the deepened Aleutian Low (Nakanowatari et al. 2015).

In recent years, new observations and technologies have become available to provide more accurate estimates of the ocean state, for example the Argo profiling float network established in approximately 2005 ("Data and methods") (Riser et al. 2008, 2016; Roemmich et al. 2009; Freeland et al. 2010). Besides, advanced data assimilation technique allows the assimilation of multiple types of observations into models, such as the Estimating the Circulation and Climate of the Ocean version 4 release 3 (ECCO v4.3) product ("Data and methods"), which is traditionally grouped as an ocean state estimate.
Based on advanced observations and reanalysis (state estimate) products, there is an accumulation of evidence showing the importance of salinity in understanding climate variability on inter-annual and decadal scales (Hasegawa et al. 2013; Hasson et al. 2013; Vinogradova and Ponte 2013; Nan et al. 2015; Vinogradova and Ponte 2017). For instance, as a passive response to El Niño-Southern Oscillation (ENSO) states, ocean salinity changes in the tropical Pacific have been used to improve ENSO forecasts (Singh et al. 2011; Qu et al. 2014; Zheng et al. 2014; Zhu et al. 2014). The interannual salinity change on the continental shelf in the Northwest Atlantic, which is mainly controlled by the wind-driven horizontal ocean advection, can be used as an indirect indicator to the change of shelf biological system (Grodsky et al. 2017). In addition, the decadal change of upper ocean salinity has been detected in some recent works. Based on the repeat hydrographic data, the Subtropical Mode Water (STMW) (Masuzawa 1969) is observed with a significant decadal salinity variation, which is salter (freshening) during the stable (unstable) Kuroshio Extension (KE) periods during the last 2 decades. This decadal salinity variation can serve as a response to the decadal variability in water exchange between the saltier subtropics and the fresher mixed water region across the KE. However, this mechanism still needs to be further investigation because it cannot explain the rapid freshening for the last 2 decades (Oka et al. 2017). It has been found that since the late 1990s, SSS changes in the tropical western Pacific Ocean were modulated by the change of the Walker circulation and associated ocean processes, reflecting the results of the Pacific decadal climate change (Du et al. 2015). The relationship between SSS trends and global water cycle in the past 2 decades were investigated by Vinogradova and Ponte (2017). They suggested that the SSS trends in the Pacific Ocean were highly correlated with the ocean salt transports and the natural decadal variability. However, the detailed mechanisms modulating the decadal variability of the subsurface salinity changes in the Pacific Ocean are not yet clear.

This paper first shows the observed salinity changes in the upper $2000 \mathrm{~m}$ since 1990s, we find a shift of vertical salinity trend at around $200 \mathrm{~m}$ : the salinity increased in upper $200 \mathrm{~m}$ but decreased within $200-600 \mathrm{~m}$ in this century. On this basis, we will focus on the upper- $200 \mathrm{~m}$ change in this study and then investigate the potential mechanism of this observed change. The rest of the paper is organized as follows: the datasets and processing methods are briefly described in Sect. 2. The observed upper ocean salinity changes are shown in Sect. 3. In Sect. 4, a salinity budget analysis is used to examine the contributing factors of the upper salinity change in the Pacific Ocean during the $2005-2015$ period. Further analysis is conducted to investigate the formation of this salinity pattern and its linkage to 
the climate mode. Finally, the discussion and summary are given in Sect. 5.

\section{Data and methods}

\subsection{Observed gridded salinity data}

A new version of the EN4 ocean objective analysis product (EN4.2.1) from the UK Met Office Hadley Centre is used in this study, which spans 1940-2017, with an Expendable Bathythermograph (XBT) bias in temperature data corrected using the Gouretski and Reseghetti (2010) scheme. The monthly potential temperature and salinity fields in the EN4 data have a resolution of $1^{\circ}$ by $1^{\circ}$ horizontally and 42 levels vertically from sea surface to $5500 \mathrm{~m}$. The in situ observations used in EN4 are obtained from the World Ocean Database (WOD13) (Boyer et al. 2013), the Global Temperature-Salinity Profile Program (GTSPP), the Array for Real-time Geostrophic Oceanography (Argo), and the Arctic Synoptic Basin-wide Observations (ASBO) (Levitus et al. 2009; Good et al. 2013).

Four Argo-based salinity gridded products are also used including the Scripps Institution of Oceanography (SCRIPPS) (Roemmich and Gilson 2009), the Japanese Agency for Marine-Earth Science and Technology (JAMSTEC) (Hosoda et al. 2008), the Global Ocean Argo gridded data set (BOA) (Lu et al. 2018), and the National Center for Environmental Information (NCEI) (Levitus et al. 2012). These monthly datasets have the same horizontal resolution as the EN4 data, but span only from the early 2000s to now. All the pressure levels are converted to depths before the analyses. The difference among the five analyses reveals the uncertainty in mapping the three-dimensional temperature and salinity fields which are outputs from the quality-control process, the mapping method, and the selection of data for construction. For instance, SCRIPPS and BOA analysis use only Argo profiles to map the ocean state, while EN4, JAMSTEC, and NCEI analyses include an Argo dataset, conductivity-temperature-depth profilers (CTD), bottles, and other in situ observations. The NCEI and BOA use slightly different Objective Interpolation techniques based on Barnes (1964), the other three analysis are all differently implemented Optimal Interpolation (OI) methods.

\subsection{ECCO estimate}

ECCO v4.3 is the latest solution of the Massachusetts Institute of Technology General Circulation Model (MITgcm) (Marshall et al. 1997a, b), which runs from 1992 to 2015. The model has a truly global domain (including the Arctic) with 50 vertical layers $(10 \mathrm{~m}$ within $150 \mathrm{~m}$ of the surface, gradually increasing to $450 \mathrm{~m}$ toward the bottom), $1^{\circ}$ zonal resolution, and spacing meridional resolution approximately $1^{\circ}$ at mid-latitudes and gradually reduced to $1 / 3^{\circ}$ within $10^{\circ}$ of the equators. It assimilates multiple sources of ocean observations (Wunsch et al. 2009; Forget et al. 2015), including Argo, in situ ocean observations, Altimetry sea surface height, various satellite measurements with the Soil Moisture and Ocean Salinity (SMOS) (Reul et al. 2014), NASA Aquarius/SAC-D (Lagerloef 2012) and the Soil Moisture Active Passive (SMAP) missions. Through the efficient adjoint method (Heimbach et al. 2005), initial conditions, surface boundary conditions, and internal parameters are optimized to retain the availability of data in a physically and statistically consistent manner. Another remarkable advantage of the adjoint-based estimates is that they obey known conservation rules exactly and are free of artificial internal heat and freshwater sources/sinks, allowing closed salinity tracer (e.g. temperature and salinity) budgets diagnostics (Ponte and Vinogradova 2016; Piecuch et al. 2017; Vinogradova and Ponte 2017; Zhang et al. 2018).

In this study, ECCO v4.3 will be used to analyze the ocean salinity budget. It will also be used to investigate how the atmosphere and ocean processes caused the salinity changes. Therefore, some other outputs from ECCO v4.3, such as the surface wind components, sea surface temperature (SST), evaporation (E), precipitation (P), are also used.

\subsection{Salinity budget analysis}

The control volume analysis used to formulate the salinity budget is described by,

$$
\begin{aligned}
& \frac{\partial}{\partial t}\left(\frac{\iiint_{V} S d V}{V}\right)=F+A D V+R e s \\
& F=\frac{1}{V} \iint_{A} S(E-P-R+\vartheta) d x d y
\end{aligned}
$$

and

$A D V=\frac{1}{V} \iiint_{V}-\nabla \cdot(S \mathbf{u}) d V$

where $S$ is salinity; $t$ is time; $V$ and $A$ are the volume and surface area of the domain, respectively; $F$ is the net air-sea freshwater flux, and includes evaporation $(E)$ minus precipitation $(P)$ minus runoff $(R)$, and $\vartheta$ is salt flux. The salt flux means the surface flux of salt, which represents the contribution of the brine rejection processes. Since the value of $\vartheta$ is set to zero except in the sea ice-covered regions, the effect of this term on the salinity budget can be neglected in our study area, where is within $60^{\circ} \mathrm{S}-60^{\circ} \mathrm{N}$. The term $A D V$ is the resolved salinity advective fluxes. Res is the residual of the salinity flux which fully represents the diffusive processes 
at the base of the control volume. The velocity components $(u, v, w)$ are the zonal, meridional and vertical velocities, respectively. To express the salinity budget at the upper $200 \mathrm{~m}$ for a control volume and close the budget, here we begin with the governing equation for conservation of salinity in a model grid cell and then average them as a control volume within the upper $200 \mathrm{~m}$ layer. In practice, the interface between vertical layers of model that is closet to this depth $(Z=194.7 \mathrm{~m})$ is used. The time-variable contributing terms in the budget, are calculated as a vertically integrated volume and then divided by the total volume $V$. The above calculations provide the mean salinity tendency in the control volume and ensure the budget closure.

\subsection{Moisture budget analysis}

The European Centre for Medium-Range Weather Forecasts Interim Reanalysis (ERA-Interim) product is also used (Berrisford et al. 2011; Dee et al. 2011). The resolution of this data is: $1^{\circ}$ horizontal grid with 37 pressure levels (top level at $100 \mathrm{hPa}$ ) and the data spans from 1979 to present, which covers Argo period. The data mainly involves evaporation, precipitation, wind components, specific humidity and the divergence of vertically integrated moisture transport, etc. The monthly precipitation analysis from the Global Precipitation Climatology Project (GPCP) Version 2.3 (Adler et al. 2003), the evaporation analysis from the Objectively Analyzed air-sea Fluxes (OAFlux) project Version 3 are also collected (Yu and Weller 2007) to obtain an E-P field. The observational and reanalysis precipitation and evaporation are used to access the reliability of freshwater change from ECCO.

The atmospheric moisture budget is used to diagnose the extent to which changes in atmospheric circulation affect E-P (freshwater) as well as the physical mechanisms for changes in E-P over the domain (Seager et al. 2010; Seager and Henderson 2013; Li et al. 2016). The governing equation is

$\Delta(P-E)=-\frac{1}{g} \Delta \int_{0}^{P_{s}} \nabla \cdot(q \boldsymbol{V}) d p+$ Res.

In Eq. (2.1), $P$ is precipitation, $E$ is evaporation from the ocean surface to the atmosphere, $\nabla^{\leftarrow}$ is the horizontal gradient operator, $\Delta$ is the time derivative operator. The term $-g^{-1} \Delta \int_{0}^{P_{s}} \nabla \cdot(q V) d p$ is the moisture flux convergence (MFC), with $g$ the acceleration due to gravity, $q$ the specific humidity, and $\boldsymbol{V}$ the horizontal wind velocity vector. The residual term (Res) represents the imbalance of reanalysis datasets. To quantify MFC, the moisture flux $q \boldsymbol{V}$ is first calculated at each pressure level and is then integrated from the surface to the top of the model level (100 hPa in ERA-interim reanalysis).
The main goal of this work is to determine what causes the moisture flux convergence or divergence (MFC or MFD) anomalies and subdivide them into components related to changes in circulation and humidity anomalies. Hence, the MFC can be decomposed as follows:

$$
\begin{aligned}
-\frac{1}{g} \Delta \int_{0}^{P_{s}} \nabla \cdot(q \boldsymbol{V}) d p= & -\frac{1}{g} \Delta \int_{0}^{P_{s}} q \nabla \cdot \boldsymbol{V} d p \\
& -\frac{1}{g} \Delta \int_{0}^{P_{s}} \boldsymbol{V} \cdot \nabla q d p \\
= & -\frac{1}{g} \int_{0}^{P_{s}} \Delta \bar{q}\left(\nabla \cdot \boldsymbol{V}^{\prime}\right) d p \\
& -\frac{1}{g} \int_{0}^{P_{s}} \Delta\left(\boldsymbol{V}^{\prime} \cdot \nabla \bar{q}\right) d p \\
& -\frac{1}{g} \int_{0}^{P_{s}} \Delta q^{\prime}(\nabla \cdot \overline{\boldsymbol{V}}) d p \\
& -\frac{1}{g} \int_{0}^{P_{s}} \Delta\left(\boldsymbol{V} \cdot \nabla q^{\prime}\right) d p+\text { Res }
\end{aligned}
$$

In Eq. (2.2), overbars and primes denote climatological mean and deviations from the mean, respectively. The first two terms on the right-hand side quantify the dynamic contribution to MFC involving changes in wind without changes in specific humidity. The latter two terms on the right represent the thermodynamic contributions involving specific humidity but no changes in winds. The residual term includes the climatology of both specific humidity and wind, which remains constant throughout the analysis period, and the covariance of the thermodynamic and dynamic contributions, which is usually an order of magnitude smaller than the dynamic and thermodynamic contributions. They are neglected since they are negligible compared to the other terms.

It is possible to further decompose the dynamic and thermodynamic contributions into flow divergence (subscript $D$ ) and advection of moisture (subscript $A$ ) terms, as shown here

$D C_{A}=-\frac{1}{g} \int_{0}^{P_{s}} \Delta\left(\boldsymbol{V}^{\prime} \cdot \nabla \bar{q}\right) d p$

$D C_{D}=-\frac{1}{g} \int_{0}^{P_{s}} \Delta \bar{q}\left(\nabla \cdot V^{\prime}\right) d p$

$T C_{D}=-\frac{1}{g} \int_{0}^{P_{s}} \Delta q^{\prime}(\nabla \cdot \overline{\boldsymbol{V}}) d p$

$T C_{A}=-\frac{1}{g} \int_{0}^{P_{s}} \Delta\left(\overline{\boldsymbol{V}} \cdot \nabla q^{\prime}\right) d p$. 
The data analyzed in this study have a monthly resolution during the 1992-2015 period, in accordance with the time coverage of ECCO v4.3. Here, this paper focuses on not only the details of the spatial distribution of changes (linear trend) within the region, but the overall decadal changes that are integrated over the volume. To emphasize decadal variability, here and throughout the paper we apply a low-pass filter (greater than 7 years) to remove the impacts of seasonal cycles and inter-annual variability. The Sen's slope method is adopted to calculating the linear trends of the salinity in different observations and the ECCO estimate. The Mann-Kendall trend tests are used to evaluate the 5\% significance level of the trends. In the Sen's slope estimators, the linear trend in time series is then computed by a median value of the slope estimates of all lines through each pair of two-dimensional sample points (Sen 1968). Based on the non-parametric test, this method is efficient to type variables and ordinal variable (Gilbert 1987). The standard errors of the linear trends are obtained from the upper and lower limits of the $95 \%$ confidence interval of the trend estimates.

The significance of the regression coefficients at the $10 \%$ significance level has been testified using the standard twotailed Student's $t$ test. Following the method of Bretherton et al. (1999), the effective degrees of freedom $N^{*}$ are calculated as:

$N^{*}=(N-1) \frac{1-r_{x} r_{y}}{1+r_{x} r_{y}}$

where $N$ is the length of sample year, $r_{x}$ and $r_{y}$ are the 12-month-lag auto-correlation of two time series of interest, respectively.

\subsection{Earth system model simulations}

To investigate the impact of key climate variability (mainly Interdecadal Pacific Oscillation, IPO) on upper salinity changes, simulations based on the Community Earth System Model, version 1 (CESM1) are used in this study. The fully coupled 2200-year pre-industrial (PI) control simulation without external or anthropogenic forcing is obtained from the CESM Large Ensemble Project (LENS) (Kay et al. 2015). This simulation provides an assessment to the contribution of various modes of internal variability to salinity changes. This model has a nominal resolution of $1^{\circ}$ by $1^{\circ}$ horizontally and 60 levels vertically from 5 to $5375 \mathrm{~m}$ for temperature and salinity fields. In this study, the period is limited to the last 1000 years of the PI control simulations to avoid the potential impacts of other forcings such as greenhouse gases and also minimize the spurious "climate drift" due to deep ocean adjustment following $\mathrm{Hu}$ et al. (2017). However, using the full 2200-year control did not make a significant difference for our analysis. The model outputs are interpolated to regular resolution of $1^{\circ}$ by $1^{\circ}$ horizontally to facilitate comparison with other data, and a linear trend was removed to further reduce the impact of "climate drift".

\section{Ocean salinity changes during the Argo period}

The linear salinity trend in the upper 200 m ocean (S200) during the Argo era (2005-2015) shows a clear contrast with that the long-term trend during the pre-Argo era (1950-2004) (comparing Fig. 1a with Fig. 1b). The pattern of long-term S200 trend during the pre-Argo era resembles the SSS trend identified in literature (Durack and Wijffels 2010; Skliris et al. 2014), showing an intensification of the climatology-mean SSS pattern, with saltier (increased values) in the salinity maxima and freshening in the salinity minima zones (Fig. 1a). This long-term spatial pattern reflects the intensification of the hydrological cycle due to global warming (Durack 2015; Jan et al. 2018). However, Argo-period S200 trend (Fig. 1b) shows a broad increase in the Tropical North Pacific $\left(0^{\circ}-30^{\circ} \mathrm{N}\right)$, the southern limb of South Pacific subtropical gyres $\left(40^{\circ} \mathrm{S}-20^{\circ} \mathrm{S}\right)$, and the West Indian Ocean $\left(30^{\circ} \mathrm{E}-60^{\circ} \mathrm{E}\right)$. And $\mathrm{S} 200$ decreased in the subtropical Atlantic Ocean, the Central and Eastern Tropical Pacific, Southeast Indian $\left(30^{\circ} \mathrm{S}-10^{\circ} \mathrm{S}\right)$, the Indonesian Through Flow (ITF) and the South China Sea. Moreover, the magnitude of the Argo-period S200 trend is approximately 10 times larger than the long-term trends during the preArgo era (Fig. 1a vs b).

On global average, the upper $200 \mathrm{~m}$ layer has experienced a marked salinity increase, accompanied by a slight salinity decrease for 200-600 m during Argo era (Wang et al. 2017). This notable vertical contrast can be found in all of the ocean analysis products and ECCO estimate (Fig. 1c). This is again quite different from the long-term salinity trend, which suggests a vertical contrast between upper thermocline (salinity increase in the upper $\sim 100 \mathrm{~m}$ ) and intermediate waters (freshening within $\sim 600-1000 \mathrm{~m}$ ) (Helm et al. 2010). The pattern and magnitude difference for the $\mathrm{S} 200$ trend during the Argo-period compared with the long-term trend indicates that a significant regulation of decadal variability on the long-term trend.

The basin-averaged vertical salinity trends over the 2005-2015 period, are provided in Fig. 1d (ECCO) and Fig. 1e (ensemble mean of all observational products). A strong positive salinity trend above $200 \mathrm{~m}$ and a freshening for the 200-600 m layer is found in the Pacific Ocean, which is consistent with the vertical structure of the global mean change. It should be also noted that the strong freshening in the Atlantic and Indian Oceans is more consistent with the global mean trends at the upper $100 \mathrm{~m}$, which is available to analyze in the future study. However, due to its largest area, 
Fig. 1 The linear trends of 0-200 m mean salinity during two different periods: a 1950-2004; b 2005-2015. The trend in $\mathbf{a}$ is EN4 data, and $\mathbf{b}$ is the ensemble mean of all observational datasets: SCRIPPS, JAMSTEC, EN4, BOA, and NCEI (units: psu/year). Black contours are the 0-200 m mean salinity climatology. The dotted areas indicate that the linear trends are statically significant at the $95 \%$ confidence level based on a modified MannKendall test. c Linear trends of the global-mean ocean salinity change at different vertical levels from surface to $2000 \mathrm{~m}$ during 2005-2015 (units: $10^{-3} \mathrm{psu} /$ year). Curves show five different observational analyses and their ensemble mean (shown in black), together with ECCO v4.3 result in red. The shadings show the $95 \%$ confidence interval of trend for the ensemble mean of observations using Sen's slope method. $\mathbf{d}$ and $\mathbf{e}$ are the salinity trends from 2005 to 2015 in each ocean basin based on ECCO v4.3 and the ensemble mean of observations, respectively (units: $10^{-3} \mathrm{psu} / \mathrm{year}$ ). The global ocean (black, GLO) and three major basins: Pacific (red, PAC), Atlantic (purple, ATL) and Indian (green, IND) Ocean $\left(60.5^{\circ} \mathrm{S} \sim 65^{\circ} \mathrm{N}\right)$ are included, and the shadings show the $95 \%$ confidence interval of the trend
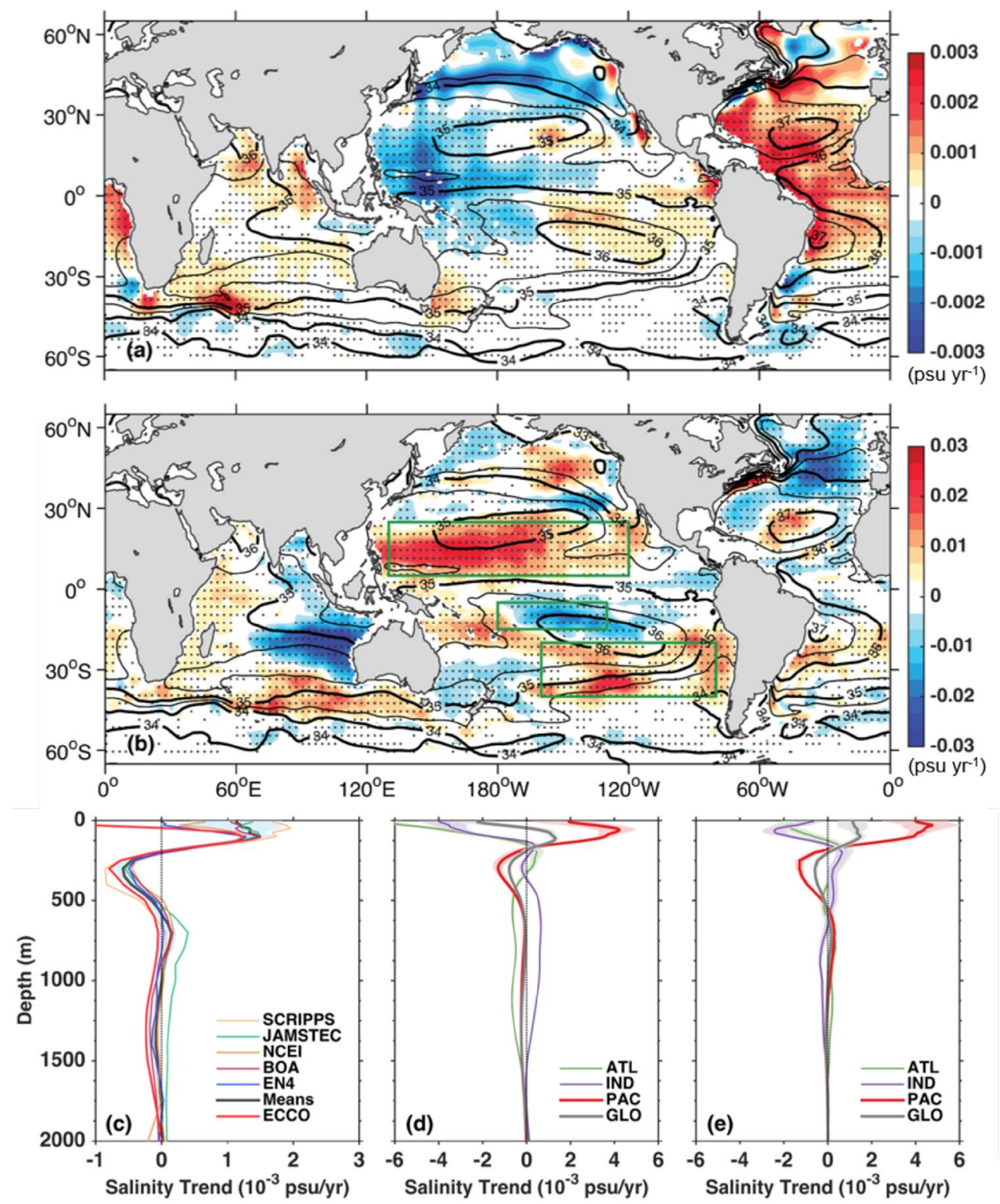

the salinity trend of Pacific is an important contributor to the global mean trend. A significant increase of salinity is found in most parts of the Pacific Ocean at the upper $200 \mathrm{~m}$ from 2005 to 2015 (Fig. 1b), which largely explains the global mean trend. And the vertical variation of salinity trend for the global ocean is more consistent with the Pacific Ocean, so it appears that the Pacific basin is the most important in shaping the total global salinity change. On this basis, this study will focus on the salinity change in the Pacific Ocean in the upper- $200 \mathrm{~m}$ and elucidate the salinity pattern and its drivers in the past decade.

\section{Upper salinity analysis in the Pacific Ocean}

\subsection{Salinity budget in the upper $200 \mathrm{~m}$ based on the ECCO}

The Pacific basin mean S200 time series $\left(65^{\circ} \mathrm{S}\right.$ and $60^{\circ} \mathrm{N}$ ) after 1994 are shown in Fig. 2a based on ECCO data, compared with observations. ECCO data shows a decrease of S200 at the linear rate of $-1.95 \times 10^{-3} \mathrm{psu} /$ year from 1994 to 2005, and an increase of S200 (linear rate $\sim 2.22 \times 10^{-3}$ psu/year) from 2005 to 2015 . For comparison, the ensemble mean from five observational 
Fig. 2 a S200 anomaly (S200a) in the Pacific Ocean from 1994 to 2015 based on the ECCO v4.3 (units: psu) shown in shading and black line. The anomaly is calculated by removing the salinity climatology defined as a mean salinity within the 2005-2015 period. The results of five observational datasets: EN4, JAMSTEC, SCRIPPS, NCEI, BOA and their ensemble means are also included; $\mathbf{b}$ and $\mathbf{c}$ are the tendency of the S200 during the two periods: 1994-2004 (P1) and 2005-2015 (P2), respectively (units: psu/ year). Black contours are the $\mathrm{S} 200$ climatology during 2005-2015. Green boxes show the NTP (upper), STP (middle), and SSG (below) regions as defined before in this study

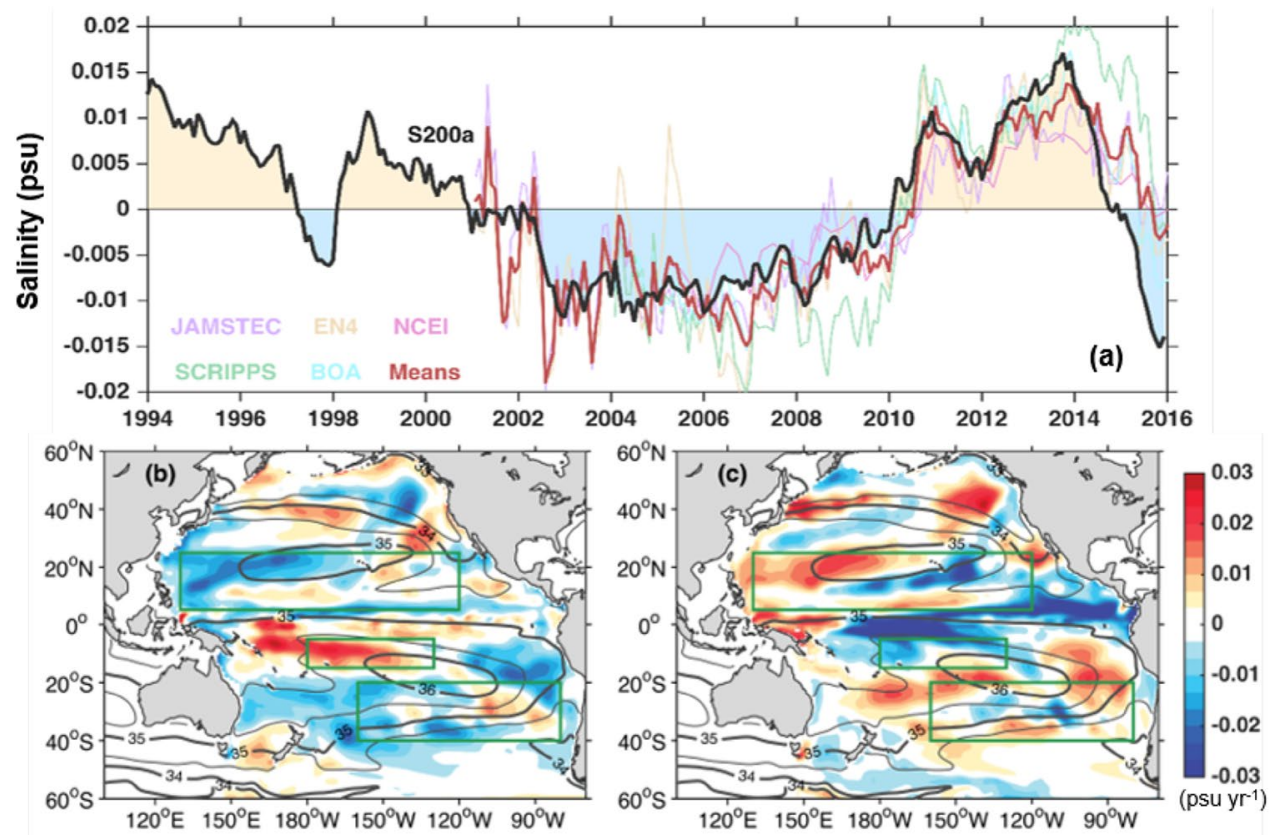

datasets indicates a linear trend of $2.90 \times 10^{-3} \mathrm{psu} / \mathrm{year}$ for S200 during the 2005-2015 period, consistent with ECCO data. We also compared the spatial pattern of the linear trend of S200 in ECCO v4.3 with other observation data for the 2005-2015 period (Supplementary Fig. S1). It is seen that ECCO v4.3 can reproduce the observed spatial pattern of S200 trends (Fig. 1b). The comparison of ECCO with other observational products in Fig. 2a together with Fig. 1 and Supplementary Fig. S1 suggests that the ECCO v4.3 can reliably capture the decadal variations of the Pacific S200 increase after 1990s. ECCO v4.3 provides a complete and, physically consistent description of the ocean beyond what is measured and this information is useful for inferring potential mechanisms of the observed salinity changes.

Considering the reversal of the salinity change in the 1990s and 2000s (Fig. 2), we use the 1994-2004 period as reference period (P1) to understand the salinity increase during the 2005-2015 period (P2). Note that P1 starts from 1994 rather than 1992 (the start of ECCO data) for a consistent time window of the two periods (11 years). The spatial pattern of the S200 tendency (S200t) during P1 and P2 are provided in Fig. 2b, c, respectively, with their difference (P2-P1) shown in Fig. 3a. First, the S200t mean during P2 (Fig. 2c) shows a similar pattern to the observed linear trend during P2 (Fig. 1b), suggesting that the S200t can reflect the main characteristics of linear trends. It also implies that the linear trend during P2 is stronger than the other variability of the S200. But there are also some regional differences partly because the calculation of S200t term can be impacted by the strong inter-annual variability in the tropics (particularly for ENSO) (Gao et al. 2014; Zheng and Zhang
2015). It is also worth noting that the observed S200 linear trend is an approximation of the long-term salinity change using statistical methods (i.e. Sen's slope method used in this study), which is subjected to errors and thus will not close the salinity budget. However, the S200t term is a parameter in ECCO and ensures the closure of salinity budget, so it is used throughout this study in the budget analysis. In addition, the opposite phase of S200 difference are found in the Fig. $2 b$ and c. Using P2-P1 can highlight the key changes in the recent period related to the previous one, and also helps to reduce the potential systematic error in ECCO simulations. Comparing Fig. 3a with Fig. 2c, the difference of the S200t between P2 and P1 (LHS term), shows a similar pattern to the S200t and observed linear trend during P2 $(\sim 2$ times stronger for $\mathrm{P} 2-\mathrm{P} 1$ than $\mathrm{P} 2)$, suggesting that it is reasonable to examine $\mathrm{P} 2-\mathrm{P} 1$ using ECCO data to understand the decadal changes.

According to the salinity budget equation in Eq. (1.1), the salinity difference between $\mathrm{P} 2$ and $\mathrm{P} 1$ should be dominated by three terms: surface freshwater inputs (Fig. 3b), ocean dynamics (Fig. 3c) and the other processes which are collected into a residual term (Fig. 3d). Here the ocean dynamics includes the total advection involving both horizontal and vertical advection. Freshwater is the net surface forcing contribution from E-P, river runoff and others. The residual term, which represents the contribution of the diffusive processes, is relatively weaker than the other terms in most parts of the Pacific Ocean and therefore negligible compared with other terms and the total S200t (comparing Fig. 3d with Fig. 3a-c). It has to be noted that, in specified regions (e.g. the Kuroshio Extension), the salinity diffusive processes might be comparable to the advective and 


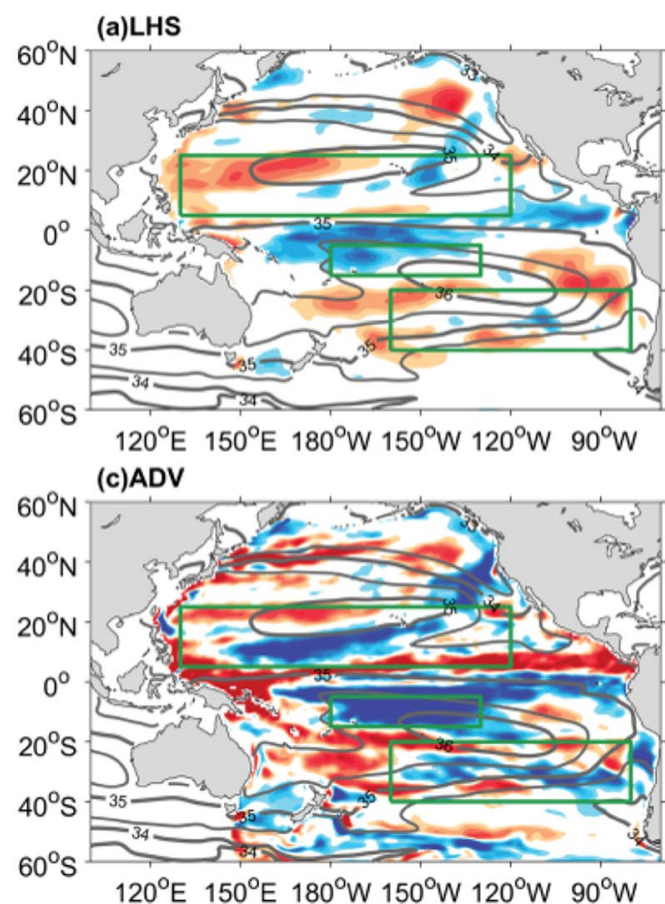

Fig. 3 The S200 tendency difference between P2 and P1 (LHS) over the Pacific Ocean (shadings; psu/year) shown in a, with its contributors: b freshwater flux (Fres); $\mathbf{c}$ Ocean advection (ADV) and $\mathbf{d}$ residual term. Positive values indicate the salinity increase from P1 to P2.

freshwater forcing terms due to the strong nonlinear dynamic interactions. However, to understand the large-scale salinity change, the residual term can be neglected bearing in mind of the uncertainties that may be generated by the salinity diffusion.

The increased net freshwater deficit into the atmosphere (Fig. 3b) is found in off-equatorial central Tropical Pacific to the east of the subtropical ocean regions. At the same time, the Indo-Pacific warm pool along the ITCZ and northwest/ southwest Pacific has received a freshwater input (related to P1). At the same time, the total advection (Fig. 3c) has an overall adverse effect compared with the surface freshwater, and contributes to the S200t balance. Figure 3 also indicates that the magnitude of both surface freshwater flux and total ocean advection is about two times larger than the salinity tendency, which suggests an overall compensation between the two terms. The ocean advection dampened the net surface forcing of freshwater, which implies the role of ocean circulation in redistributing the basin-scale heat/salinity budget.

Complicated spatial variability emerges in $\mathrm{P} 2$ compared with $\mathrm{P} 1$, the difficulty is to clarify the relative contributions from different mechanisms in different locations. To provide a quantification of the contributions from surface fluxes and ocean advection, as in Eq. (1.1), we focus on three key areas to examine the mechanisms in detail. Two of the three key
(b)Fres

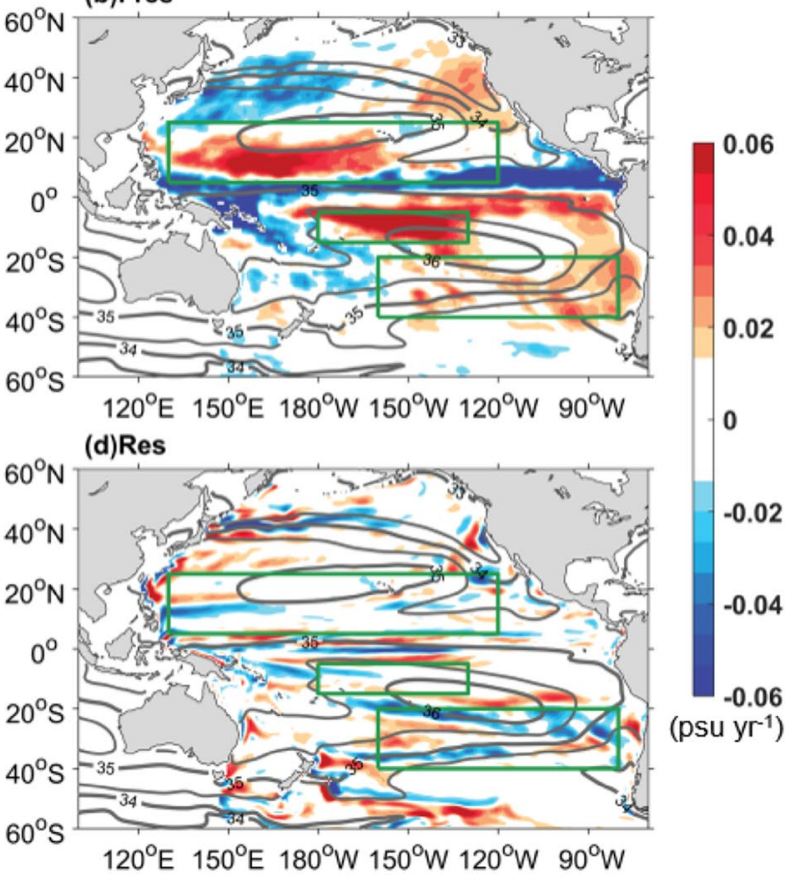

Black contours are the S200 climatology during 2005-2015. Green boxes mark the NTP (upper), STP (middle), and SSG (below) regions as defined before in this study

regions show a significant S200 increase: the North Tropical Pacific (NTP; $5^{\circ}-25^{\circ} \mathrm{N}, 130^{\circ} \mathrm{E}-120^{\circ} \mathrm{W}$ ) and the southern limb of the South Pacific Subtropical Gyre (SSG; $20^{\circ}-40^{\circ} \mathrm{S}$, $\left.170^{\circ} \mathrm{W}-120^{\circ} \mathrm{W}\right)$. One key region reflects a remarkable salinity decrease: the Southern Tropical Pacific (STP; $5^{\circ}-15^{\circ} \mathrm{S}$, $180^{\circ}-130^{\circ} \mathrm{W}$ ).

Related to the reference period P1, Fig. 4a shows the regionally-integrated $\mathrm{S} 200$ budget in these regions, including the freshwater flux, total advection, and the residual. It appears that $\mathrm{S} 200$ changes in all three regions, are mainly due to the combination of the surface freshwater flux and oceanic transports. In the NTP and STP, the contribution of freshwater flux and advection is opposite, the intensified ocean freshwater deficit $(\mathrm{E}-\mathrm{P}>0)$ increases S200 but the total advection tends to dampen S200. However, in the NTP, freshwater deficit dominates and results in net increase of S200, but in the STP, the total advection dominates and results in a net decrease of S200. This suggests a redistributing role of ocean processes for surface forcing. Different from both NTP and STP, the regional-mean advection and freshwater forcing terms in the SSG contribute in the same phased to $\mathrm{S} 200$ increase. It is noted that the residual term is negligible in NTP and STP regions, but may not valid in the SSG, which is comparable to the advection term in SSG but in opposite phase. This suggests that the advective term is approximately balanced 
Fig. 4 S200 m budget (P2-P1) in the three key regions (units: psu/year) in a: overall salinity tendency term (LHS, red), salinity advection term (ADV, yellow), freshwater flux (Fres, wathet), and salinity trend (S200, orange); b shows the surface freshwater budget (P2-P1): Fres (red), E-P (EMP, pink), evaporation (Evap, white), negative precipitation [Pres(1), wathet], and residuals (Res, blue). Three key regions include NTP (Left), STP (middle) and SSG (Right). The values in NTP and SSG are scaled by 4 for better illustrations. Positive values indicate the salinity increase. The error-bar for S200 in a shows the $95 \%$ confidence interval of S200 linear trend and the other error bars in $\mathbf{a}$ and $\mathbf{b}$ show one standard error of the mean, representing the uncertainty in calculating the box-mean from the values inside the box
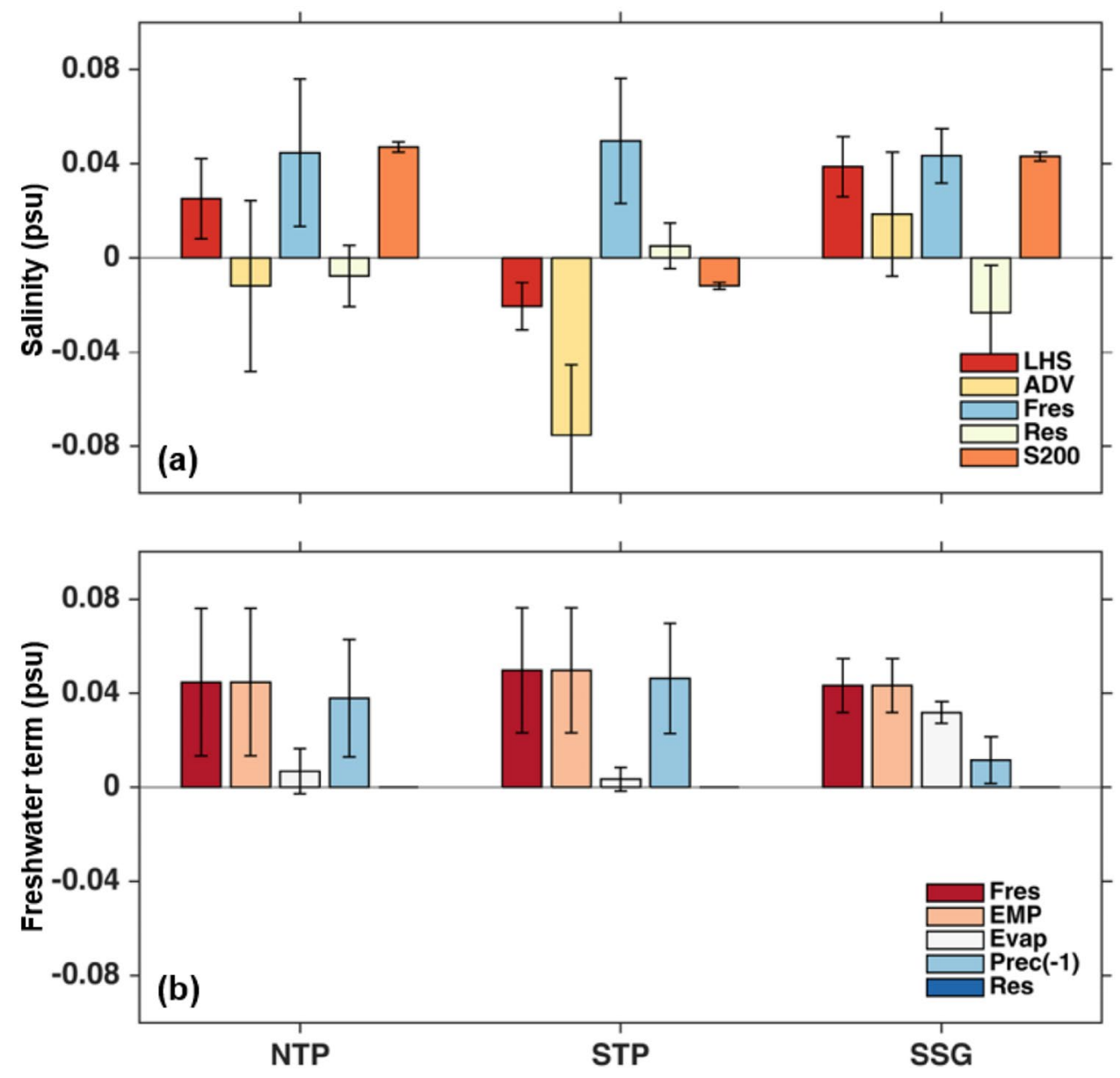

by the diffusive processes. As indicated in Fig. 3d, the contribution of the diffusive processes reveals a "striation" like pattern near the eastern boundary close to Southern America, where the energy can be radiated by the nonlinear instability from the eastern boundary (Wang et al. 2012, 2013b). Here, it was proposed a strong diffusive process with ocean eddy activities, which is related to the energy radiated from boundary current, might be important in balancing the salinity advection and budget. A future dynamic analysis will be further investigated but beyond of this study.

The differences in the dominant term for the three key regions indicate the different controlling processes at different locations. It is also noted here that in Fig. 4, values in NTP and SSG are scale by 4 to be comparable with STP changes, because the budget terms are greater in the tropics (STP) than at higher latitudes (NTP and SSG). Supplementary Fig. S2b also shows that the magnitude of S200t variation is two times smaller than the surface freshwater flux and total ocean advection. These findings reveal the stronger air-sea interactions in the tropics.

In terms of the freshwater flux term, the large ocean freshwater loss to the atmosphere is apparent in all three key regions. The freshwater loss in these regions are accompanied by the freshwater input into the ocean along the equatorial Pacific Ocean $\left(5^{\circ} \mathrm{N}-5^{\circ} \mathrm{N}\right)$ and Northwest pacific $\left(20^{\circ}-40^{\circ} \mathrm{N}\right)$. It is then intriguing to know what process is responsible for the freshwater change. We investigate the contributions from evaporation (Evap, $\frac{1}{V} \iint_{A} S(E) d x d y$ ), precipitation (Prec, $\frac{1}{V} \iint_{A} S(-P) d x d y$ ), and the residue involving river run-off and ice-sheet melting (Res), as in Eq. (1.2) (Fig. 4b). It is evident that the positive freshwater anomalies are almost entirely explained by the E-P changes in these regions. Specifically, Fig. $4 \mathrm{~b}$ shows that the negative precipitation anomaly accounts for $\sim 85 \%$ and $\sim 88 \%$ of the freshwater lose in the NTP and STP, respectively. Meanwhile, the evaporation anomaly plays a minor role $(\sim 15 \%$ and $\sim 12 \%)$. However, in the SSG, evaporation dominates the freshwater deficit ( $73 \%$ ), while the negative precipitation anomaly plays a secondary role $(\sim 26 \%)$.

The spatial pattern of the two main components of the freshwater terms (evaporation and negative precipitation) are provided in Fig. 5 based on ECCO data. Generally, the E-P (freshwater) pattern is consistent with the precipitation pattern (Fig. 3c), suggesting the dominant role of precipitation changes. The evaporation anomaly reinforces the 


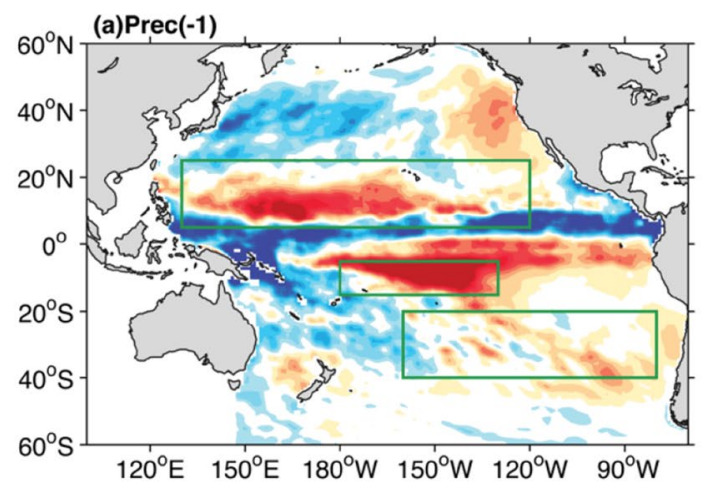

Fig. 5 Decompositions of time-averaged freshwater flux (related to S200) for the difference between P2 and P1 (units: psu/year): a negative precipitation rate, denoted as Prec $(-1), \mathbf{b}$ evaporation rate,

precipitation patterns in most of the Pacific Ocean (Fig. 5b), implying a linkage between precipitation and evaporation. This finding is consistent with our analyses for the three key boxes (Fig. 4b). Our key findings are also evident for other observational and reanalysis products (i.e. E-P, $-\mathrm{P}$ and $\mathrm{E}$ ), for instance, $\mathrm{P}$ and $\mathrm{E}$ in the GPCP and OAFlux observational products respectively (Supplementary Fig. S3), E and $\mathrm{P}$ in ERA-Interim reanalysis product (Supplementary Fig. S4), although there are some regional differences due to the uncertainty in surface flux data (Yu et al. 2017).

\subsection{Moisture budget in the Pacific based on ERA-Interim}

It was shown in Sect. 4.1 that the surface freshwater flux, dominated by precipitation (E-P), plays a key role in setting the observed salinity patterns, which is then dampened and regulated by ocean advections. The question remains, what controls the E-P (or freshwater flux) changes? Here, the atmospheric moisture budget based on the ERA-Interim atmospheric reanalysis is used to help us understand the sources of the atmospheric freshwater. Figure 6 analyzes the total moisture flux convergence or divergence (MFC or MFD) anomalies (P2-P1) and its main decomposing parts.

The total MFC resembles the E-P from ECCO v4.3 in Fig. 5a, c, implying its ability to explain the major part of the precipitation (E-P) change in the Pacific Ocean. Additionally, the divergent components of the moisture flux allow us to identify the regions into which these moisture fluxes will converge (arrows in Fig. 6a). It shows the freshwater transport from the subtropics, particularly in the Southern Hemisphere, toward the tropical Pacific. As a result, the MFC in the regions of intense tropical convergence, such as the ITCZ and SPCZ, increases by $0.3 \mathrm{~m} /$ year (Fig. 6a) to induce a larger precipitation (P-E) there (Fig. 5). Meanwhile, in the Tropical North Pacific $\left(5-20^{\circ} \mathrm{N}\right)$ and Southeast Pacific

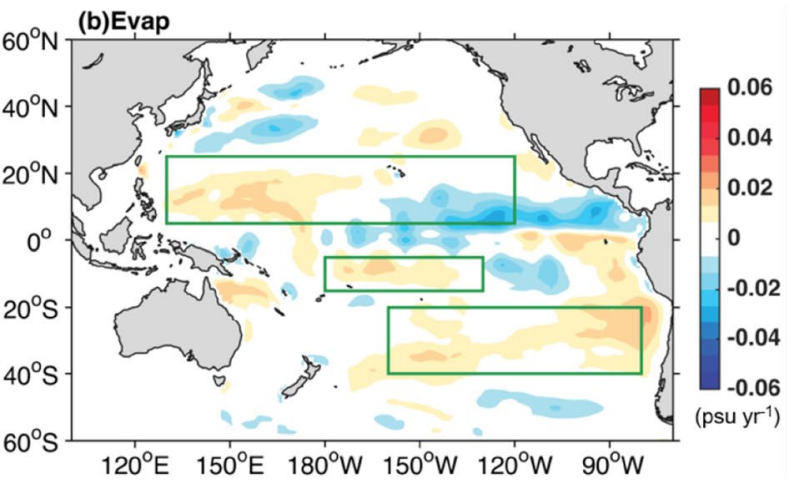

denoted as Evap. Green boxes mark the NTP (upper), STP (middle), and SSG (below) regions as defined before in this study

$\left(5-40^{\circ} \mathrm{S}\right)$, the MFC signal moves equatorward and westward to the Tropical Ocean, contributing to the broad precipitation loss (positive E-P) in this region. Meanwhile, the anomalous MFD in the Tropical North Pacific is relatively smaller than that in the Southern hemisphere and corresponds to a slightly weaker divergent component of moisture flux. This may be related to the asymmetric SST distribution maintained by the wind-evaporation-SST (WES) feedback (Xie and Philander 1994). The MFC change can be separated into thermodynamic and dynamic contributions due to atmospheric circulation changes and humidity anomalies, respectively, as derived in Eq. (2.2) (Fig. 6). The dynamic contributions include the wind divergence change $\left(\mathrm{DC}_{D}\right.$, shown in Fig. 6b) and the wind advection of humidity $\left(\mathrm{DC}_{A}\right.$, shown in Fig. $\left.6 \mathrm{c}\right)$, both are associated with the wind anomalies, as indicated in Eqs. (2.3) and (2.4). Figure $6 \mathrm{~b}$ shows that $\mathrm{DC}_{D}$ term, which represents the effect of change in the wind divergence with a climatological humidity, highly resembles with the MFC pattern in the Pacific. Therefore, the wind divergence is the major contributor of the MFC changes.

The $\mathrm{DC}_{A}$ term, which highlights the moisture advection due to the wind change with a fixed humidity gradient (Fig. 6c), is much smaller than $\mathrm{DC}_{D}$ with a pattern similar to the $\mathrm{DC}_{D}$ pattern. Besides of the dynamic terms, thermodynamically, the change of humidity by the anomalous humidity gradient $\left(\mathrm{TC}_{A}\right.$, shown in Fig. $\left.6 \mathrm{~d}\right)$ and the circulation divergence by changing the water vapor content $\left(\mathrm{TC}_{D}\right)$ shown in Eqs. (2.5) and (2.6), also contributes to the E-P change. However, the $\mathrm{TC}_{A}$ is a non-uniform effect and favors the E-P gain in the western Pacific $\left(20^{\circ} \mathrm{N}-40^{\circ} \mathrm{S}\right)$, while the $\mathrm{TC}_{D}$ plays a negligible role (not shown here). In summary, the decomposing analysis of the surface freshwater budget suggests that the dynamic contribution associated with wind anomalies is a major contributor in the Pacific in recent decades, whereas the thermodynamic contributions play a minor role. 

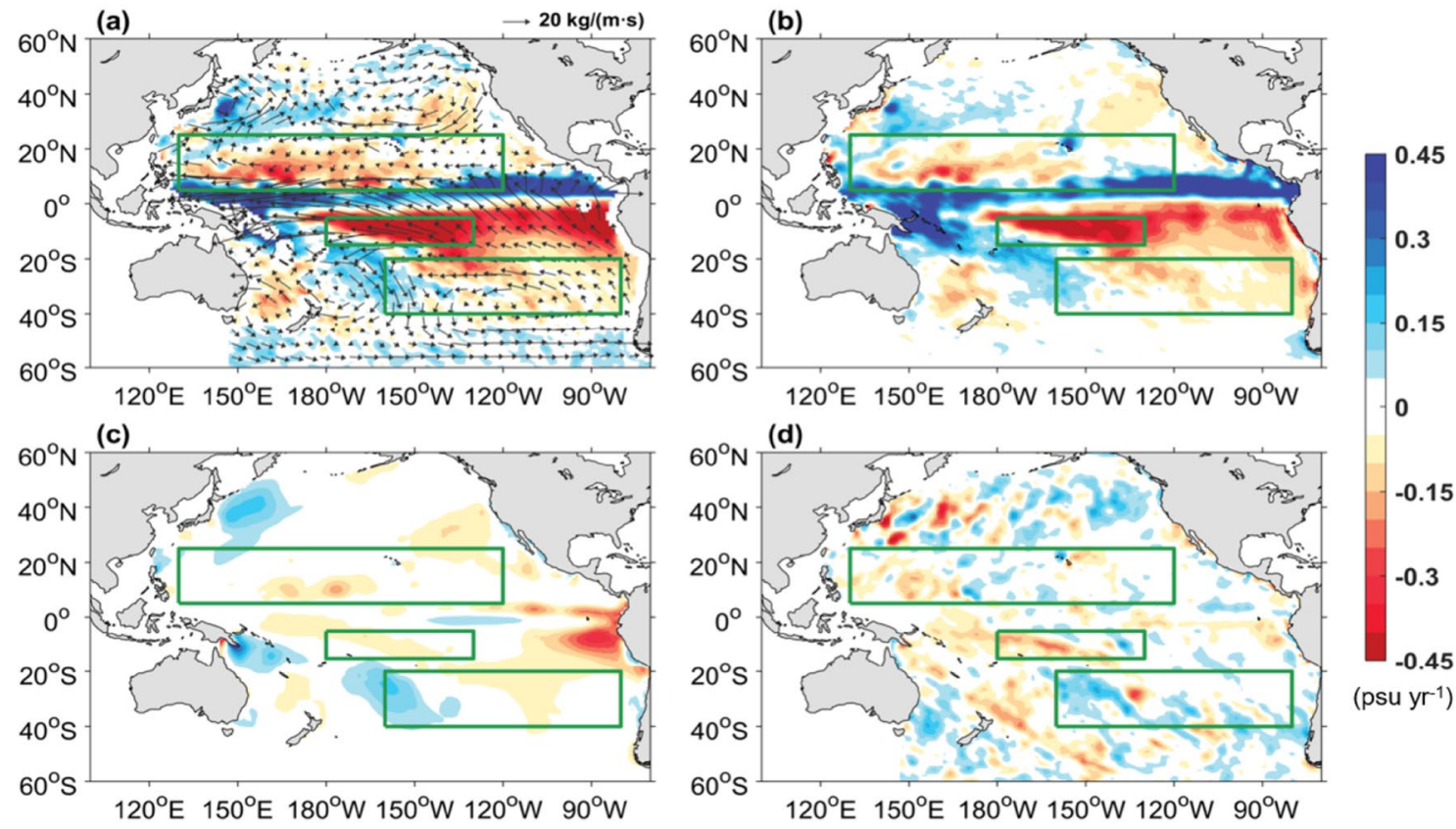

Fig. 6 The moisture budget (P2-P1): a total MFC (shadings; m/year) and its divergent components [vectors; $\mathrm{kg} /(\mathrm{m} \cdot \mathrm{s})$ ]; and the main contributors to the MFC changes (shadings; m/year): $\mathbf{b}-\frac{1}{g} \int_{0}^{P_{s}} \Delta \bar{q}\left(\nabla \cdot V^{\prime}\right) d p$;

$\mathbf{c}-\frac{1}{g} \int_{0}^{P_{s}} \Delta\left(\boldsymbol{V}^{\prime} \cdot \nabla \bar{q}\right) d p ; \mathbf{d}-\frac{1}{g} \int_{0}^{P_{s}} \Delta\left(\overline{\boldsymbol{V}} \cdot \nabla q^{\prime}\right) d p$. Green boxes mark the NTP (upper), STP (middle), and SSG (below) regions as defined before in this study

\subsection{Processes controlling the freshwater and advection changes}

In the previous sections, we explored the local salinity budget in the Pacific. Both surface freshwater flux and ocean dynamics are important but their relative importance varies with location. In addition, the moisture budget analysis suggests that the dynamics contribution associated with wind anomalies can largely account for the E-P (surface freshwater) change in the Pacific. So, other questions arise: What role do the wind activities play in contributing to the freshwater and advection processes? Are there linked? These issues will now be explored.

\subsubsection{Wind-driven surface freshwater changes}

It has been shown that the wind divergence $\left(\mathrm{DC}_{D}\right)$ dominates the surface freshwater budget, highlighting the linkage between freshwater and wind anomalies (Fig. 6). Given the dramatic decrease in specific humidity with height, the $\mathrm{DC}_{D}$ anomalies can be derived mainly from the low troposphere (Wang et al. 2013a). Figure 7a shows the differences of surface wind (vectors) between P2 and P1. The agreement between low-level wind divergence anomalies (Fig. 7) and divergent components of moisture transport (Fig. 6a) indicate a primary role of the low-level anomalous winds. In general, the low-level

anomalous wind convergence (divergence) is consistent with the ascending (descending) anomalies in the middle troposphere that leads to enhanced (reduced) precipitation (Fig. 6b).

As shown in Fig. 7, in the trade winds regions, a slightly weak anomalous wind anticyclone occurs in the center of NTP and a stronger and wider divergent anomalous wind happens in the South Pacific, which is closely related to the intensification of trades in recent decades (England et al. 2014). In the Southwest Pacific, there is a strong anomalous wind convergence that appears to the east of New Zealand, causing a zonal dipole precipitation pattern that is drier in the west and wetter to the east. Furthermore, Fig. 7 shows that a wind convergence occurs in the eastern Pacific ITCZ (north of the equator), reflecting a strengthening of crossequatorial winds (southerly winds across the equator) in the eastern Pacific. The climatological cross-equatorial winds regions are related to a strong meridional SST gradient and a northward-displaced ITCZ (Hu and Fedorov 2018). The enhanced cross-equatorial Hadley cell leads to a stronger wind convergence and favors more rainfall in this region (related to P1), consistent with the result shown in Fig. 5a.

\subsubsection{Wind-driven anomalous ocean advection}

In Sect. 4.1, ocean advection was shown to play an important role in the formation of upper ocean salinity patterns. 
Fig. 7 The difference (P2-P1) of lower-tropospheric wind divergence (shadings; $10^{-7} / \mathrm{s}$ ) and wind (vectors; $\mathrm{m} / \mathrm{s}$ ). The lower-tropospheric wind is defined as the average of the wind within $1000-850 \mathrm{hPa}$

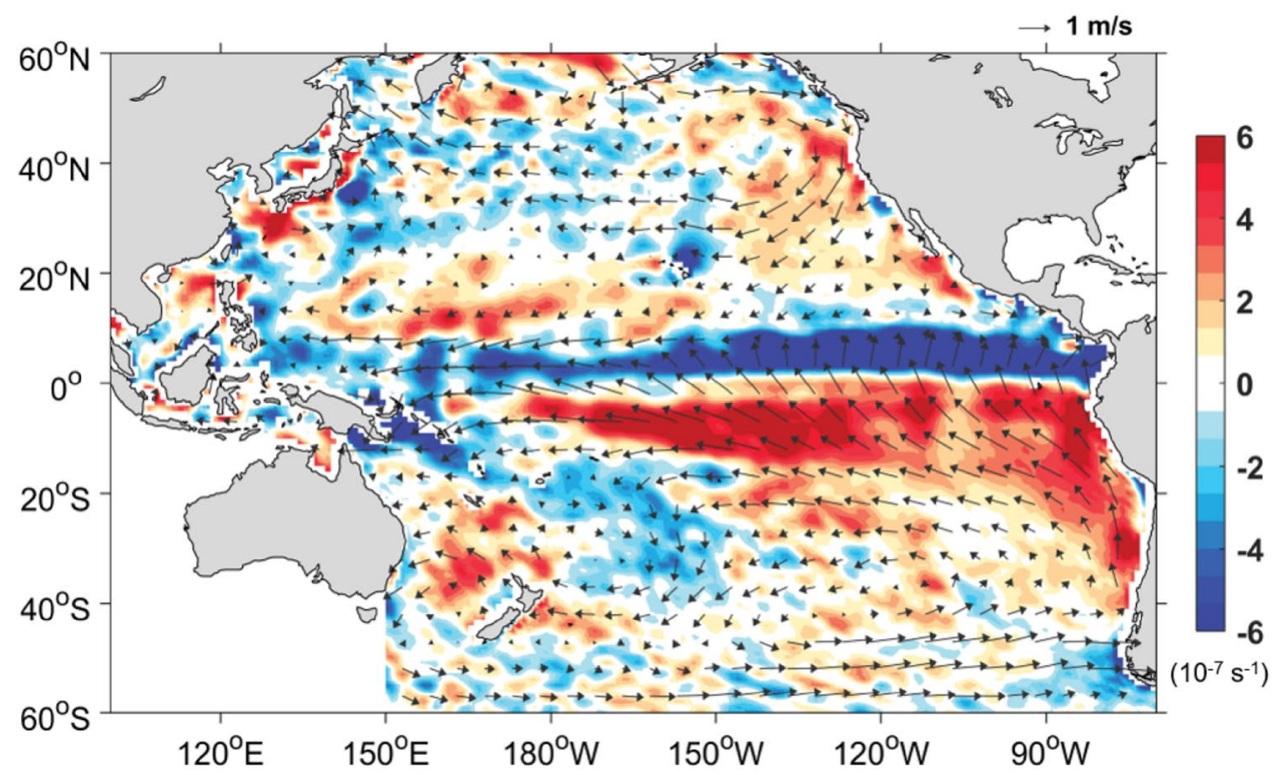

Horizontal and vertical salinity advection are further separated in Figs. 8b and c. They reflect an opposing contribution to the total advection with the magnitudes of $\sim 10$ times greater than the total advection term. This suggests that the upper-200 m oceanic transports in the horizontal and vertical directions are strong and equally important during P2 (related to P1).

The Pacific shallow overturning circulation plays an important role in connecting the tropical and subtropical ocean, and its change is mainly driven by the modulation of wind forcing (McCreary and Lu 1994). A recent intensification of Pacific trade winds has been detected to accelerate the Pacific shallow overturning cells, which leads to the redistribution of mass, heat and salt (McPhaden and Zhang 2004; England et al. 2014; Song et al. 2018). Compared to the period P1 (Fig. 9c), the shallow subtropicaltropical overturning cells during $\mathrm{P} 2$ have been enhanced and concentrated within a shorter latitude range (Fig. 9d), which is sinking at about $20^{\circ} \mathrm{N}$ in the north and $15^{\circ} \mathrm{S}$ in the south, and rising in the tropics. In the subtropical cells, more extratropical water with higher salinity is subducted into the thermocline. It then converges into the tropical pycnocline and finally upwells to the surface in the equatorial Pacific, which contributes to a S200 increase from the western equatorial Pacific to the North Pacific ITCZ region. Meanwhile, the fresher water in the tropics will be transported into the higher latitudes and contributes to the S200 decrease between the minimum salinity region associated with the ITCZ to the subduction regions. The increased equatorial pycnocline convergence in the ocean interior is linked to an acceleration of equatorial undercurrent (EUC) and associated upwelling in the East Pacific causes a S200 increase (Fig. 8c). Furthermore, the horizontal and vertical advection terms seem to feature a cross distribution varying with latitude, which is associated with the change of zonal currents. Such an intensified zonal mean flow shear motivates a strong exchange of vertical turbulence. In the subtropics, the excess evaporation over precipitation generates a net removal of freshwater, and this E-P deficit can be compensated by some ocean processes, manifesting an injection of lower-salinity waters from the surrounding regions. It is found that there is a net convergence of surface-layer water and downward motion due to the Ekman transport within the subtropical gyres, which is also a general equatorial drift forced by the wind stress curl (Gordon and Giulivi 2008). Consequently, the wind stress curl caused by wind forcing might be important to the wind-driven ocean circulation and advection processes in the subtropics. In the North of $15^{\circ} \mathrm{N}$ (e.g. including the northern part of the NTP), it appears a positive advection $\left(\sim 20^{\circ} \mathrm{N}\right)$ accompanied by a negative anomaly at $\sim 15^{\circ} \mathrm{N}$ (Fig. 8a). It might be associated with the declining westerlies and weakened North Pacific wind stress curl in the recent decades, which reduced the Kuroshio transports (Wang et al. 2016; Wu et al. 2017). The weaker negative wind stress curl brought less freshwater into the northern part, contributing to the S200 increase. In the South of $20^{\circ} \mathrm{S}$, increased wind stress curl is associated with the cyclonic wind pattern. It weakens the southward transports from the tropics, contributing to the increasing trend of S200, together with the high local E-P deficit.

In summary, different regional modulations driven by the wind circulations in the recent decades correspond to the regional changes of upper ocean advection processes, and further contribute to the decadal adjustment of S200 transport in the Pacific. 
Fig. 8 Decompositions of the advection budget (P2-P1) (shadings; psu/year): a total advection with surface winds (vectors; $\mathrm{m} / \mathrm{s}$ ); and its main components: b horizontal advection term and $\mathbf{c}$ vertical advection term. The arrows in a are with the key at the top right. Black contours express the S200 climatology during 2005-2015

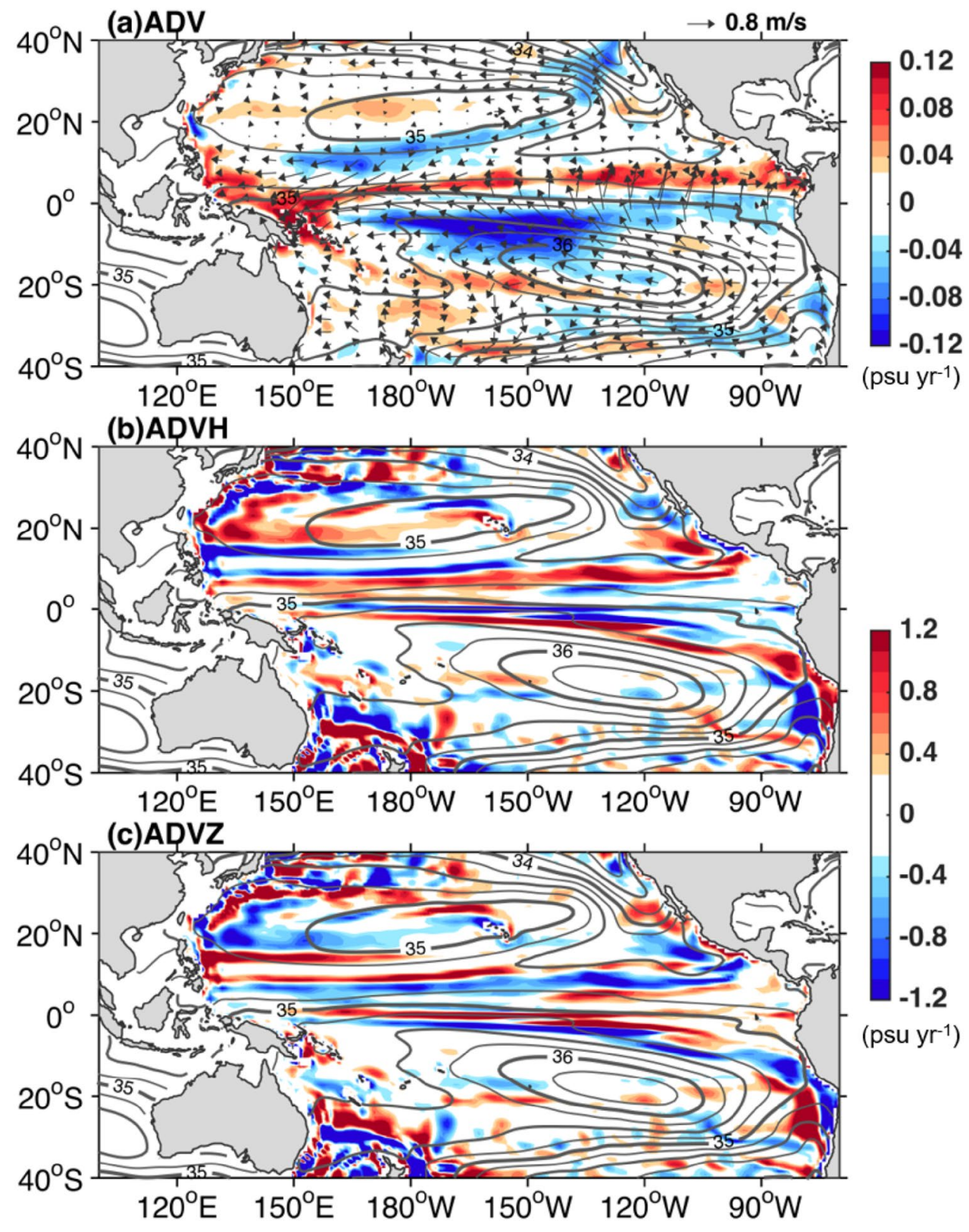

\subsection{The linkage to large-scale climate variability mode}

In previous sections, it is shown that the sea surface wind changes play an important role in modulating the ocean salinity fields through both surface freshwater (dominated by precipitation) and ocean advection. In this section, the potential contribution of the Interdecadal Pacific Oscillation (IPO) in the observed salinity pattern in this decade will be investigated.

IPO is the dominate mode of air-sea interactions on decadal scales in the Pacific, which has its imprints on the sea surface temperature, winds, precipitations, etc. (Folland et al. 2002; Dai 2013). It is well documented that IPO has shifted into a negative phase since the late 1990s, which is characterized by northwest and southwest Pacific warming and eastern Pacific cooling and strengthened surface trade winds over the Pacific (Trenberth et al. 2014; Henley et al. 2015; Zhang 2016). The SST difference (P2-P1) exhibits such an IPO-like pattern (Fig. 10a). Meanwhile, the development of a negative IPO phase has contributed to the intensification of the Pacific Walker circulation since the late 1990s (Mcgregor et al. 2014; Du et al. 2015) and stronger Hadley circulation over Pacific (Feng et al. 2011; Nguyen et al. 2013). The SLP difference pattern (P2-P1), with a lower SLP in their ascending branches and higher pressure in their descending regions, corresponds well with the intensifications of both Walker circulation and 
(a) Zonal mean salinity (P1)

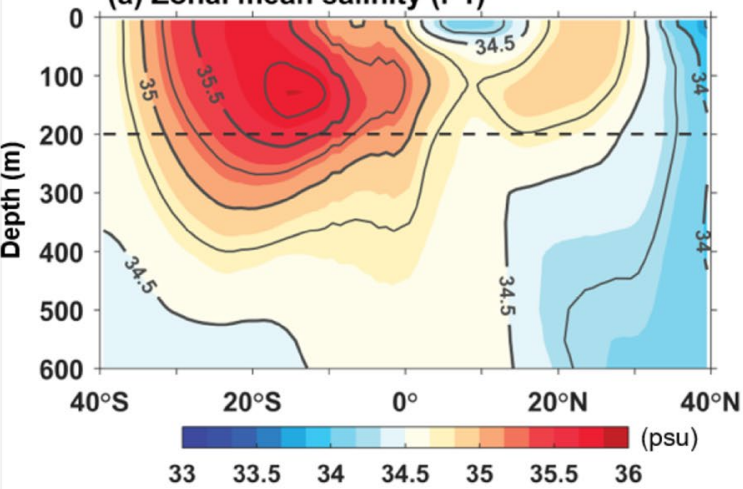

(c) Mean meridional streamfunction (P1)

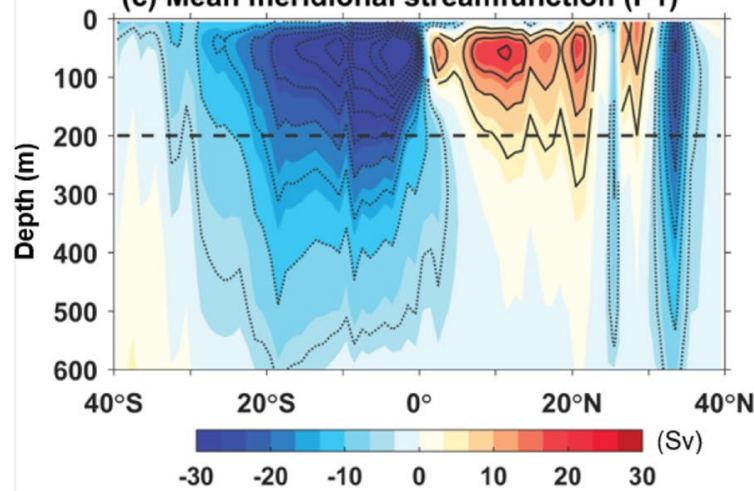

Fig. 9 Zonal mean salinity and the meridional streamfunction, and their changes: a the climatological-mean salinity during 1994-2015 over the Pacific Ocean (units: psu); b the difference (P2-P1) of salinity tendency (Units: psu/year); The contours in $\mathbf{a}$ and $\mathbf{b}$ denote the zonal mean salinity climatology. c climatological-mean meridional overturning streamfunction over the Pacific Ocean (units: Sv); (b) Salinity tendency (P2-P1)

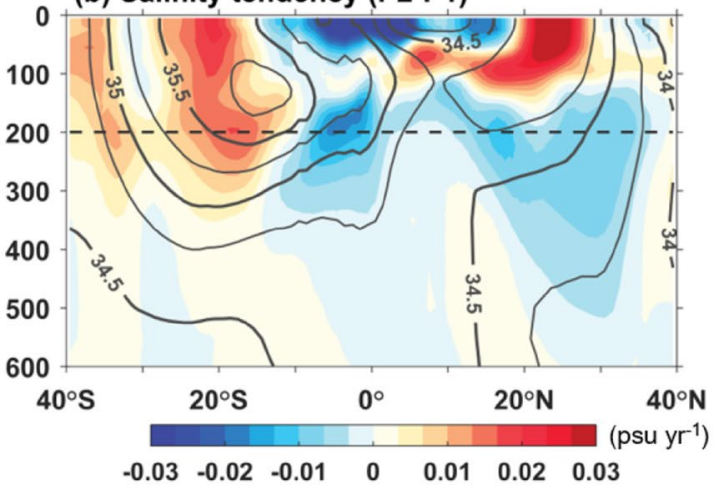

(d) Meridional streamfunction (P2-P1)

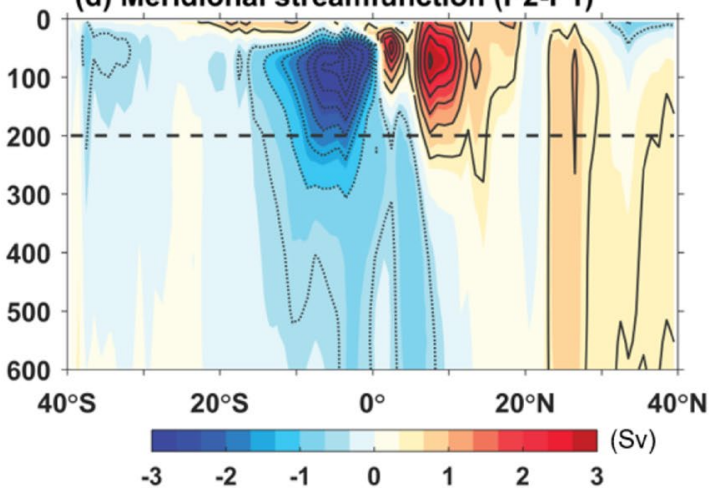

d difference (P2-P1) of meridional overturning streamfunction. The streamfunction is calculated based on the seawater meridional velocity and is zonally integrated in the Pacific Ocean. Red shading in $\mathbf{c}$ and $\mathbf{d}$ (solid contours) denotes clockwise circulation and blue one (dashed contours) denotes anticlockwise circulation
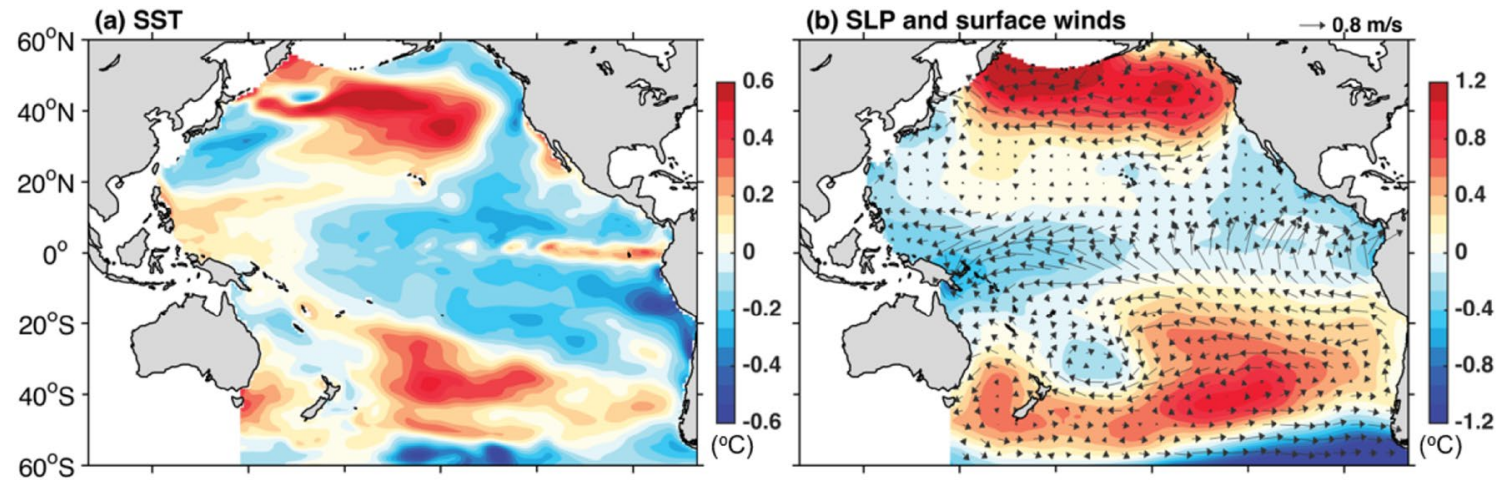

Fig. 10 The difference (P2-P1): a SST (shadings; ${ }^{\circ} \mathrm{C}$ ), b SLP (shadings; $\mathrm{hPa}$ ) and surface wind vectors at $10 \mathrm{~m}$ (vectors; $\mathrm{m} / \mathrm{s}$ ); the arrows of $\mathbf{b}$ are with the key at the top right. All the variables are derived from ECCO v4.3, except for the SLP (ERA-Interim)

Hadley circulation (Fig. 10b). Therefore, we hypothesize that the decadal salinity changes in the upper- $200 \mathrm{~m}$ discussed in previous sections may be due to the shift in IPO.

The regression map of decadal SST and S200t anomalies upon the observed negative IPO index (Henley et al.
2015) are shown in Fig. 11a and b, based on the ECCOv4.3. The regressed SST captures the major features of the IPO in the Pacific basin. Meanwhile, the spatial pattern of S200t regressed onto IPO displays a high correlation $(R=0.7)$ with the S200a linear trend during P2, that is significant at the 
(a) SST vs IPO (-)

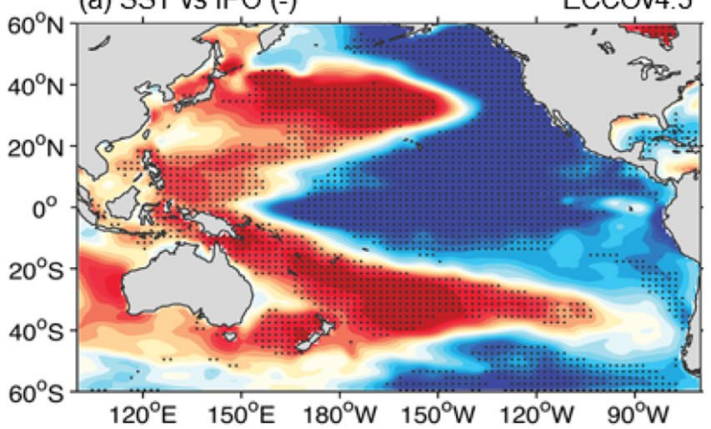

(c) SST vs IPO (-)

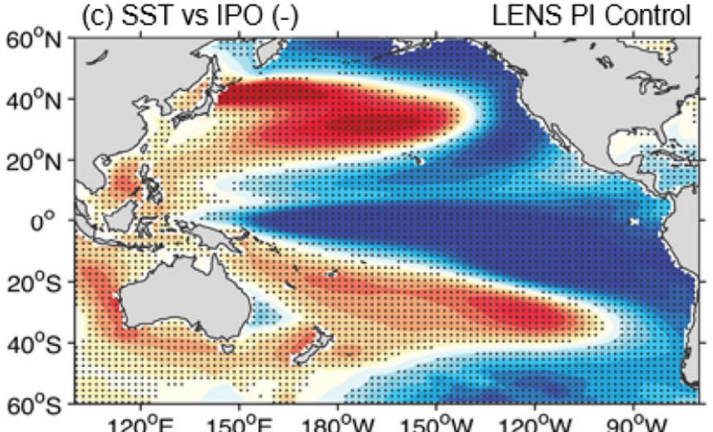

(e) SST vs IPO (-)

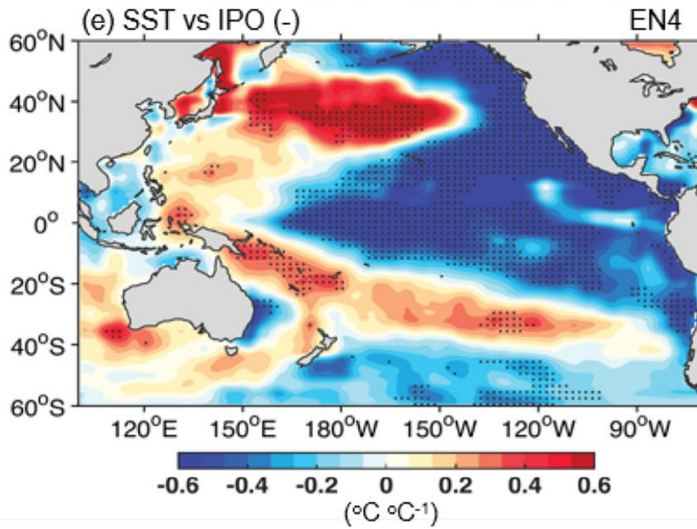

Fig. 11 Regressions of SST (a, c, e, units: $\left.{ }^{\circ} \mathrm{C} /{ }^{\circ} \mathrm{C}\right)$ and $\mathrm{dS} 200(\mathbf{b}$, $\mathbf{d}$, f, units: $10^{-3} \mathrm{psu} / \mathrm{year} /{ }^{\circ} \mathrm{C}$ ) upon negative IPO index. $\mathbf{a}$ and $\mathbf{b}$ are for ECCO v4.3, $\mathbf{c}$ and $\mathbf{d}$ for LENS, e and $\mathbf{f}$ for EN4. The low-pass

95\% confidence level (Fig. 1b). This implies an important role of IPO variability to the S200 changes in the Pacific during the past two decades.

To examine IPO-induced temperature and salinity changes in the upper ocean, we calculate the IPO index in both LENS result (1000 year PI control) and EN4 analysis (1940-2017) following the definition of Henley et al. (2015). Then we regress the SST anomalies and S200t anomalies in LENS and EN4 upon the IPO index (Fig. 11c-f). Both of data have weaknesses: LENS data might be impacted by model bias and EN4 data is short (1940-now) and overlapped with the period examined in this study (1992-2015), so EN4 results are not independent with ECCO-based results in this study. But using both of them, through assessing the consistency and discrepancy between the two datasets, can (b) dS200 vs IPO (-) ECCOv4.3

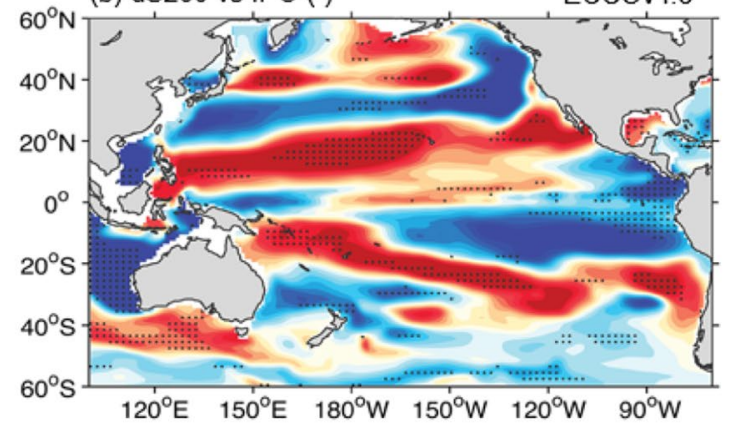

(d) dS200 vs IPO (-) LENS PI Control
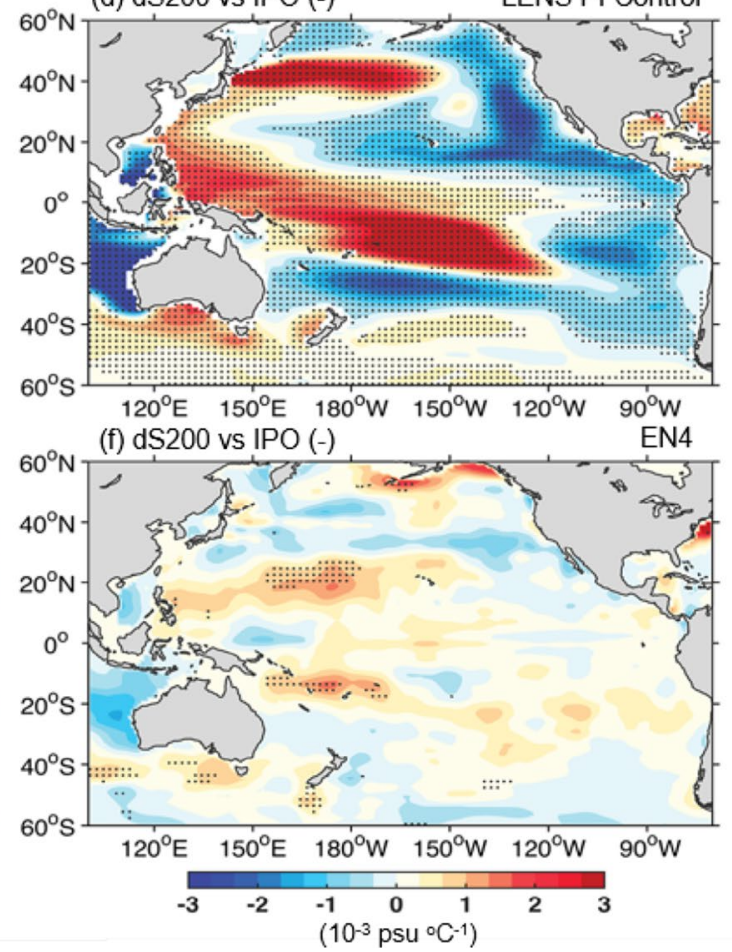

filter has been used to remove the variability with periods less than 84 months. The dotted areas indicate that the regressed coefficients are statically significant at the $90 \%$ confidence level

strongly indicate what are the robust IPO-related features and what are not.

Overall, the LENS and EN4 show similar IPO-related SST pattern (comparing Fig. 11c and e), implying a robust IPO-imprint in SST field. For S200t, the LENS- and EN4based IPO-related patterns show some consistency (Fig. 11 in cycles) including salinification over the SPCZ, to the east of the Philippines, the Kuroshio extension regions around $\sim 40^{\circ} \mathrm{N}$, and the freshening over the Tropical Eastern Pacific, Northeast and Southwest Pacific. In these regions, the IPO-related S200 changes are also consistent with the IPO-regressed S200 using ECCO data, and S200t difference (P2-P1). However, in some regions, the salinity change pattern does not show a good relationship with the IPO, including subtropical regions over the middle to eastern Pacific 
that exhibit strong freshening $\left(10^{\circ}-30^{\circ} \mathrm{N}\right.$ and in regions south of $20^{\circ} \mathrm{S}$ ), and the center of Southern Tropical Pacific. EN4 data show much weaker IPO-related changes than other data, which is likely related to the uncertainty due to the sparseness of salinity observations and the associated reconstruction methods. As stated in Good et al. (2013) and discussed in Wang et al. (2018), EN4 objective analysis might drift to "climatology" (zero-anomaly) in data sparse regions, which is a "conservative error". Notably, there is a weak zonal freshening band extending from central subtropics around $\sim 20^{\circ} \mathrm{N}$, corresponding to a disagreement between the observed ocean heat content change and IPO-related cooling (Cheng et al. 2018).

Therefore, the IPO might partly explain the decadal variation of upper ocean salinity over the Pacific. However, it should be noted that some locations cannot be explained by the IPO. This might be related to other modes of climate variability, such as ENSO and the impacts from remote locations.

\section{Discussion and Conclusion}

Recent Argo-based observations show an increase in global salinity in the upper $200 \mathrm{~m}$ and a decrease for 200-600 m after 2005, with distinctive regional patterns compared with the long-term patterns. The inter-basin comparison further demonstrates that the Pacific Ocean plays a key role in setting the global mean upper-600 m salinity changes during 2005-2015. Therefore, we examine the salinity budget based on ECCO v4.3 (between 1994 and 2015) for the upper-200 m in the Pacific Ocean. A central purpose of this budget analysis is to investigate the mechanisms of the recent decadal variations. Three key regions with maximum salinity signals in the Pacific Ocean were carefully analyzed: the Northern Tropical Pacific (NTP) and the southern limb of the South Pacific Subtropical Gyre (SSG), and the Southern Tropical Pacific (STP). An increasing salinity trend over the Tropical Northwest Pacific (i.e. in NTP box) and South Pacific (i.e. SSG) regions is found since 2005. On average, declining rainfall is the largest contributor to the increased S200 in the NTP. In the SSG, the freshwater term plays a dominant role, and the total advection also reinforces the increase of the salinity. Meanwhile, the diffusive term is important in the SSG, which has an equivalent contribution to the advection term, and might be associated with the strong eddy activities close to the eastern boundary. The freshwater loss in SSG is mainly due to the enhanced $\mathrm{E}$, while the precipitation plays a secondary role. In the STP, the ocean has been freshening since 2005, and the negative contribution of ocean advection offsets the positive contribution of the reduced precipitation. Analyses of the salinity budget in these regions suggest that both surface freshwater and ocean advection contribute to the salinity changes but their relative importance varies with locations.

We further investigate the relationship between the changes in surface forcing, ocean processes and the largescale atmospheric circulation anomalies, with a focus on the potential mechanisms causing these changes. Figure 12 shows the geographical distribution of the S200 trend during 2005-2015 and the main controlling processes related to the intensified trade winds. The trend on the latitude-depth (Pacific zonal mean), longitude-depth (averaged from $3^{\circ} \mathrm{S}$ to $3^{\circ} \mathrm{N}$ ), and longitude-latitude (S200) are illustrated together for a clear illustration of the ocean interior change. It represents the key role of surface winds in the S200 decadal change during the past decades. The strengthened trade winds motivate the anomalous wind convergence in Western Tropical Pacific and ITCZ band at $\sim 7^{\circ} \mathrm{N}$, favoring the higher rainfall (negative $\mathrm{E}-\mathrm{P}$ ) in these regions. Besides, the wind divergence occurs outside of ITCZ band (i.e. NTP and STP), and then reduces the local precipitation (positive E-P). At the same time, the intensification of trade winds enhances the shallow Pacific subtropical-tropical overturning cells and that are concentrated within a shorter latitude range. Saltier extratropical waters are subducted into the tropics and then upwell to the surface in the equatorial Pacific, contributing to the $\mathrm{S} 200$ increase in low latitudes. The injection of lower-salinity waters will converge into the subtropical cells, leading to a freshening in the subduction regions. The large-scale ocean advection has an overall adverse effect of the surface freshwater, which implies the redistributing role of ocean processes to the surface forcing for decadal time scale. Therefore, the Pacific S200 change in the past decade is mainly due to the combination of surface freshwater and ocean advection, which are largely driven by the decadal changes of the large-scale surface winds. Where do the wind anomalies come from? Are there associated with some intrinsic air-sea climate modes? We show that the IPOlike pattern of SST anomaly, accompanied by strengthened trade winds during this century, could substantially modulate the large-scale circulation changes and thus influence the observed salinity changes since 2005 . The IPO contribution to the SSS trends during 1993-2010 period was previously investigated in the Vinogradova and Ponte (2017), and they focus on SSS but this study focuses on S200 tendency. Examining tendency provides new insights as it is naturally associated with freshwater budget. We attribute the decadal S200 changes (link to S200 tendency) to the wind-driven changes in both surface freshwater and ocean advection, which can be linked to IPO. Multiple datasets including observations, reanalysis and models were used in our study, strengthening the robustness of our conclusion.

In summary, our results highlight the decadal-scale upper ocean salinity changes, which is significantly different from the long-term signal. First, the short term (i.e. 10 years) 


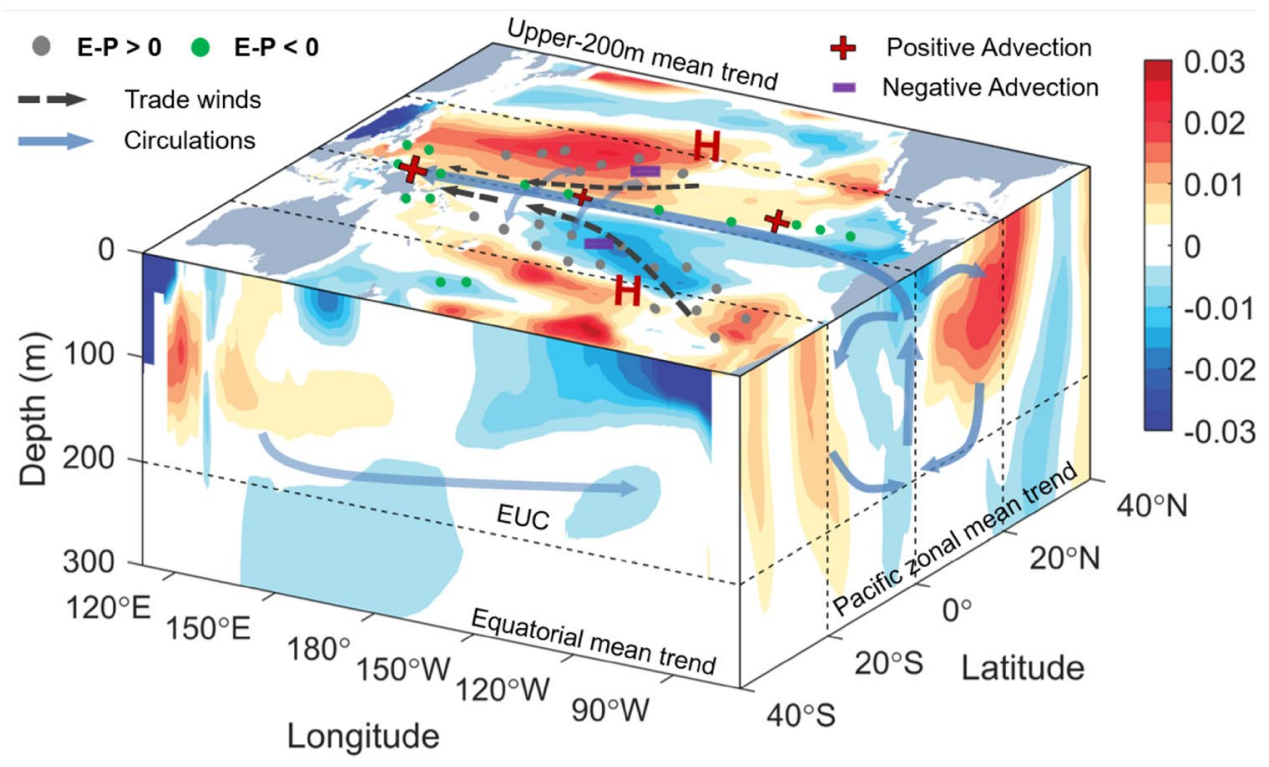

Fig. 12 Schematic diagrams of the processes explaining the formation of the upper- $200 \mathrm{~m}$ salinity changes in the Pacific during 2005-2015 (units: psu/year), based on the ECCOv4.3. The upper map (shadings) denotes the linear trend of upper-200 m salinity trend, with needed smoothing for better illustration. The E-P anomaly are doted in the surface (brown, E-P $>0$ and green, $\mathrm{E}-\mathrm{P}<0$ ). The left front

salinity variation is about one order larger than the long-term trend, which implies the upper salinity signature of decadal variability is stronger than its long-term response. We show that the decadal change of upper- $200 \mathrm{~m}$ salinity during the last two decades, balanced by the regional surface freshwater forcing and the ocean advections, are substantially modulated by the wind-driven processes. The IPO, as the major mode of decadal variability in the Pacific Ocean, plays an important role in upper salinity change at decadal time scale, but cannot fully explain the pattern.

It is worthy to discuss some caveats of this work here. Firstly, a detailed quantification on the key processes contributing to the salinity changes is needed, for instance, what is the role of subtropical gyre circulation change, subduction change, or even buoyancy forcing? For instance, the gyre circulation plays an important role in redistributing the upper ocean thermodynamics associated with the basinscale wind and climate change (Wu et al. 2012), although the basin-scale wind anomaly does not seem to exhibit a dramatic Ekman pumping input into the Pacific Ocean. Secondly, our results are mainly derived from ECCO data. Given the intrinsically evolving nature of the ocean state estimating process and potential systematic errors in results, it is intriguing to revisit the decadal variability in the future when more observations and improved ocean reanalysis products are available. map shows the linear trend of meridional mean upper-300 $\mathrm{m}$ salinity averaged from $3^{\circ} \mathrm{S}$ to $3^{\circ} \mathrm{N}$. The right section is the linear trend of zonal mean salinity over the Pacific basin. The black dotted arrow denotes the surface wind anomaly and blue thick arrow means the current anomaly. "H" denotes the areas with high SLP

Acknowledgements This study is supported by the National Key R\&D Program of China (2017YFA0603202 and 2016YFC1401800). We acknowledge support from Ichiro Fukumori, Christopher G. Piecuch, and other scientists from ECCO group for their helps in implement of ECCO data. The ECCO v4.3 solution can be downloaded here (https ://ecco.jpl.nasa.gov/products/latest/). EN4 data is available in the Met Office of the UK for EN4 analysis (https://www.metoffice.gov.uk/hadob s/en4/download-en4-2-0.html), SCRIPPS data is available at http:// sio-argo.ucsd.edu/RG_Climatology.html, JAMSTEC data is in ftp:// ftp2.jamstec.go.jp/pub/argo/MOAA_GPV/Glb_PRS/OI/, BOA data is in ftp://data.argo.org.cn/pub/ARGO/BOA_Argo/, and NCEI data is in https://www.nodc.noaa.gov/OC5/3M_HEAT_CONTENT/. The CESM LENS model output is available in https://www.earthsystemgrid.org/. The ERA-Interim data is downloaded at http://apps.ecmwf.int/datas ets/data/interim-full-moda/levtype $=\mathrm{pl} /$. GPCP monthly precipitation analysis is downloaded at http://eagle1.umd.edu/GPCP_CDR/Month ly_Data/. OAFlux evaporation data is from http://oaflux.whoi.edu/.

Open Access This article is distributed under the terms of the Creative Commons Attribution 4.0 International License (http://creativeco mmons.org/licenses/by/4.0/), which permits unrestricted use, distribution, and reproduction in any medium, provided you give appropriate credit to the original author(s) and the source, provide a link to the Creative Commons license, and indicate if changes were made.

\section{References}

Adler RF et al (2003) The version-2 global precipitation climatology project (GPCP) monthly precipitation analysis (1979-Present). J Hydrometeorol 4:1147-1167. https://doi.org/10.1175/15257541(2003)004\%3c1147:TVGPCP\%3e2.0.CO;2 
Awo FM, Alory G, Da-Allada CY, Delcroix T, Jouanno J, Kestenare E, Baloitcha E (2018) Sea surface salinity signature of the tropical atlantic interannual climatic modes. J Geophys Res Oceans 123:7420-7437. https://doi.org/10.1029/2018JC013837

Barnes SL (1964) A technique for maximizing details in numerical weather map analysis. J Appl Meteorol 3:396-409. https ://doi.org/10.1175/1520-0450(1964)003\%3c0396:ATFMD I\%3e2.0.CO;2

Berrisford P, Kallberg P, Kobayashi S et al (2011) Atmospheric conservation properties in ERA-Interim. Q J R Meteorol Soc 137:13811399. https://doi.org/10.1002/qj.864

Bosc C, Delcroix T, Maes C (2009) Barrier layer variability in the western Pacific warm pool from 2000 to 2007. J Geophys Res. https://doi.org/10.1029/2008jc005187

Boyer TP, Levitus S, Antonov JI, Locarnini RA, Garcia HE (2005) Linear trends in salinity for the World Ocean, 1955-1998. Geophys Res Lett 32:67-106. https://doi.org/10.1029/2004GL021791

Boyer TP, Antonov JI, Baranova OK et al (2013) World Ocean Database 2013. NOAA Atlas NESDIS: 72, $209 \mathrm{p}$

Bretherton CS, Widmann M, Dymnikov VP, Wallace JM, Bladé I (1999) The effective number of spatial degrees of freedom of a time-varying field. J Clim 12:1990-2009. https://doi. org/10.1175/1520-0442(1999)0121990:tenosd.2.0.CO;2

Cheng L, Wang G, Abraham J, Huang G (2018) Decadal ocean heat redistribution since the late 1990s and its association with key climate modes. Climate 6:91. https://doi.org/10.3390/cli6040091

Curry R, Dickson B, Yashayaev I (2003) A change in the freshwater balance of the Atlantic Ocean over the past four decades. Nature 426:826. https://doi.org/10.1038/nature02206

Dai A (2013) The influence of the inter-decadal Pacific oscillation on US precipitation during 1923-2010. Clim Dyn 41:633-646. https ://doi.org/10.1007/s00382-012-1446-5

de Boyer MC, Madec G, Fischer AS, Lazar A, Iudicone D (2004) Mixed layer depth over the global ocean: An examination of profile data and a profile-based climatology. J Geophys Res. https ://doi.org/10.1029/2004jc002378

Dee DP, Uppala SM, Simmons AJ et al (2011) The ERA-Interim reanalysis: configuration and performance of the data assimilation system. Q J R Meteorol Soc 137:553-597. https://doi. org/10.1002/qj.828

Du Y, Zhang Y, Feng M, Wang T, Zhang N, Wijffels SE (2015) Decadal trends of the upper ocean salinity in the tropical Indo-Pacific since mid-1990s. Sci Rep 5:16050. https://doi.org/10.1038/srep1 6050

Durack PJ (2015) Ocean salinity and the global water cycle. Oceanography 28:20-31. https://doi.org/10.5670/oceanog.2015.03

Durack PJ, Wijffels SE (2010) Fifty-year trends in global ocean salinities and their relationship to broad-scale warming. J Clim 23:4342-4362. https://doi.org/10.1175/2010JCLI3377.1

Durack PJ, Wijffels SE, Matear RJ (2012) Ocean salinities reveal strong global water cycle intensification during 1950-2000. Science 336:455. https://doi.org/10.1126/science. 1212222

England MH, Mcgregor S, Spence P et al (2014) Recent intensification of wind-driven circulation in the Pacific and the ongoing warming hiatus. Nat Clim Change 4:222-227. https://doi.org/10.1038/ nclimate2106

Fedorov AV, Pacanowski RC, Philander SGH, Boccaletti G (2004) The Effect of salinity on the wind-driven circulation and the thermal structure of the upper ocean. J Phys Oceanogr 34:1949-1966. https://doi.org/10.1175/1520-0485(2004)034\%3c1949:TEOSO $\mathrm{T} \% 3 \mathrm{e} 2.0 . \mathrm{CO} ; 2$

Feng R, Li J, Wang J (2011) Regime change of the boreal summer Hadley circulation and its connection with the tropical SST. J Clim 24:3867-3877. https://doi.org/10.1175/2011jcli3959.1

Ferry N, Reverdin G (2004) Sea surface salinity interannual variability in the western tropical Atlantic: an ocean general circulation model study. J Geophys Res Oceans 109:C05026. https://doi. org/10.1029/2003jc002122

Folland CK, Renwick JA, Salinger MJ, Mullan AB (2002) Relative influences of the Interdecadal Pacific Oscillation and ENSO on the South Pacific Convergence Zone. Geophys Res Lett 29:211-24-4. https://doi.org/10.1029/2001g1014201

Forget G, Campin JM, Heimbach P, Hill CN, Ponte RM, Wunsch C (2015) ECCO version 4: an integrated framework for nonlinear inverse modeling and global ocean state estimation. Geosci Model Dev 8:3653-3743. https://doi.org/10.5194/ gmd-8-3071-2015

Freeland HJ, Roemmich D, Garzoli SL et al (2010) Argo-A Decade of Progress. In: Proceedings of OceanObs'09: Sustained ocean observations and information for society (Vol 2), pp. 357-370. https://doi.org/10.5270/oceanobs09.cwp.32

Gao S, Qu T, Nie X (2014) Mixed layer salinity budget in the tropical Pacific Ocean estimated by a global GCM. J Geophys Res Oceans 119:8255-8270. https://doi.org/10.1002/2014JC010336

Gilbert RO (1987) Statistical methods for environmental pollution monitoring. Wiley, New York

Good SA, Martin M, Rayner NA (2013) EN4: quality controlled ocean temperature and salinity profiles and monthly objective analyses with uncertainty estimates. J Geophys Res 118:6704-6716. https ://doi.org/10.1002/2013JC009067

Gordon AL, Giulivi CF (2008) Sea surface salinity trends over 50 years within the subtropical North Atlantic. Oceanography 21:20-29. https://doi.org/10.5670/oceanog.2008.64

Gouretski V, Reseghetti F (2010) On depth and temperature biases in bathythermograph data: development of a new correction scheme based on analysis of a global ocean database. Deep Sea Res Part I Oceanogr Res Pap 57:812-833. https://doi.org/10.1016/j. dsr.2010.03.011

Grodsky SA, Reul N, Chapron B, Carton JA, Bryan FO (2017) Interannual surface salinity on Northwest Atlantic shelf. J Geophys Res Oceans 122:3638-3659. https://doi.org/10.1002/2016JC012580

Hartmann DL, Kelvin Tank AMG, Rusicucci M et al (2013) Observations: Atmosphere and Surface. In: Climate Change 2013: The Physical Science Basis. Contribution of Working Group I to the Fifth Assessment Report of the Intergovernmental Panel on Climate Change. Cambridge University Press. https://doi. org/10.1017/cbo9781107415324.008

Hasegawa T, Ando K, Ueki I, Mizuno K, Hosoda S (2013) UpperOcean salinity variability in the tropical pacific: case study for quasi-decadal shift during the 2000s using TRITON Buoys and Argo floats. J Clim 26:8126-8138. https://doi.org/10.1175/JCLID-12-00187.1

Hasson AEA, Delcroix T, Dussin R (2013) An assessment of the mixed layer salinity budget in the tropical Pacific Ocean. Observations and modelling (1990-2009). Ocean Dyn 63:179-194. https://doi. org/10.1007/s10236-013-0596-2

Heimbach P, Hill C, Giering R (2005) An efficient exact adjoint of the parallel MIT General Circulation Model, generated via automatic differentiation. Future Gener Comput Syst 21:1356-1371. https ://doi.org/10.1016/j.future.2004.11.010

Held IM, Soden BJ (2006) Robust responses of the hydrological cycle to global warming. J Clim 19:5686-5699. https://doi. org/10.1175/jcli3990.1

Helm KP, Bindoff NL, Church JA (2010) Changes in the global hydrological-cycle inferred from ocean salinity. Geophys Res Lett 37:389-390. https://doi.org/10.1029/2010GL044222

Henley BJ, Gergis J, Karoly DJ, Power S, Kennedy J, Folland CK (2015) A tripole index for the Interdecadal Pacific Oscillation. Clim Dyn 45:3077-3090. https://doi.org/10.1007/s0038 2-015-2525-1

Hosoda S, Ohira T, Nakamura T (2008) A monthly mean dataset of global oceanic temperature and salinity derived from Argo float 
observations. JAMSTEC Rep Res Dev 8:47-59. https://doi. org/10.5918/jamstecr.8.47

Hosoda S, Suga T, Shikama N, Mizuno K (2009) Global surface layer salinity change detected by Argo and its implication for hydrological cycle intensification. J Oceanogr 65:579. https://doi. org/10.1007/s10872-009-0049-1

Hu S, Fedorov AV (2018) Cross-equatorial winds control El Niño diversity and change. Nat Clim Change 8:798-802. https://doi. org/10.1038/s41558-018-0248-0

Hu Z, Hu A, Hu Y (2017) Contributions of Interdecadal Pacific Oscillation and Atlantic Multidecadal Oscillation to Global Ocean heat content distribution. J Clim 31:1227-1244. https://doi. org/10.1175/JCLI-D-17-0204.1

Jan DZ, Nikolaos S, Adam TB, Robert M, Nurser AJG, Josey SA (2018) Improved estimates of water cycle change from ocean salinity: the key role of ocean warming. Environ Res Lett 13:074036. https://doi.org/10.1088/1748-9326/aace42

Kay JE, Deser C, Phillips A et al (2015) The Community Earth System Model (CESM) large ensemble project: a community resource for studying climate change in the presence of internal climate variability. Bull Am Meteor Soc 96:1333-1349. https://doi. org/10.1175/bams-d-13-00255.1

Lagerloef GSE (2012) Satellite mission monitors ocean surface salinity. Eos Trans Am Geophys Union 93:233. https://doi. org/10.1029/2012EO250001

Lagerloef G, Schmitt RW, Schanze JJ, Kao H (2010) The Ocean and the global water cycle. Oceanography 23:82-93. https://doi. org/10.5670/oceanog.2010.07

Lago V, Wijffels SE, Durack PJ, Church JA, Bindoff NL, Marsland SJ (2016) Simulating the role of surface forcing on observed multidecadal upper-ocean salinity changes. J Clim 29:5575-5588. https://doi.org/10.1175/JCLI-D-15-0519.1

Levang SJ, Schmitt RW (2015) Centennial changes of the global water cycle in CMIP5 models. J Clim 28:6489-6502. https:// doi.org/10.1175/jcli-d-15-0143.1

Levitus S, Antonov JI, Boyer TP, Locarnini RA, Garcia HE, Mishonov AV (2009) Global ocean heat content 1955-2008 in light of recently revealed instrumentation problems. Geophys Res Lett. https://doi.org/10.1029/2008g1037155

Levitus S, Antonov JI, Boyer TP et al (2012) World ocean heat content and thermosteric sea level change (0-2000 m), 1955-2010. Geophys Res Lett. https://doi.org/10.1029/2012g1051106

Li L, Schmitt RW, Ummenhofer CC, Karnauskas KB (2016) Implications of North Atlantic sea surface salinity for summer precipitation over the US Midwest: mechanisms and predictive value. J Clim 29:3143-3159. https://doi.org/10.1175/JCLI-D-15-0520.1

Lu S, Li H, Xu J, Liu Z, Wu X, Sun C, Cao M (2018) Manual of global ocean argo gridded data set (BOA_Argo) (Version 2018), 13 p

Marshall J, Adcroft A, Hill C, Perelman LT, Heisey C (1997a) A finitevolume, incompressible Navier Stokes model for studies of the ocean on parallel computers. J Geophys Res 102:5753-5766. https://doi.org/10.1029/96JC02775

Marshall J, Hill C, Perelman LT, Adcroft A (1997b) Hydrostatic, quasihydrostatic, and nonhydrostatic ocean modeling. J Geophys Res 102:5733-5752

Masuzawa J (1969) Subtropical mode water. Deep Sea Res Oceanogra Abstr 16:463-472. https://doi.org/10.1016/0011-7471(69)90034 $-5$

McCreary JP, Lu P (1994) Interaction between the Subtropical and Equatorial Ocean Circulations: the subtropical cell. J Phys Oceanogr 24:466-497. https://doi.org/10.1175/15200485(1994)024\%3c0466:IBTSAE\%3e2.0.CO;2

Mcgregor S, Timmermann A, Stuecker MF, England MH, Merrifield M, Jin FF, Chikamoto Y (2014) Recent Walker circulation strengthening and Pacific cooling amplified by Atlantic warming.
Nat Clim Change 4:888-892. https://doi.org/10.1038/nclimate23 30

McPhaden MJ, Zhang D (2004) Pacific Ocean circulation rebounds. Geophys Res Lett. https://doi.org/10.1029/2004g1020727

Nakanowatari T, Mitsudera H, Motoi T, Ishikawa I, Ohshima KI, Wakatsuchi M (2015) multidecadal-scale freshening at the salinity minimum in the western part of North Pacific: importance of wind-driven cross-gyre transport of subarctic water to the subtropical gyre. J Phys Oceanogr 45:988-1008. https://doi. org/10.1175/JPO-D-13-0274.1

Nan F, Yu F, Xue H, Wang R, Si G (2015) Ocean salinity changes in the northwest Pacific subtropical gyre: the quasi-decadal oscillation and the freshening trend. J Geophys Res Oceans 120:2179-2192. https://doi.org/10.1002/2014JC010536

Nguyen H, Evans A, Lucas C, Smith I, Timbal B (2013) The Hadley circulation in reanalyses: climatology, variability, and change. J Clim 26:3357-3376. https://doi.org/10.1175/JCLI-D-12-00224.1

Oka E, Katsura S, Inoue H, Kojima A, Kitamoto M, Nakano T, Suga T (2017) Long-term change and variation of salinity in the western North Pacific subtropical gyre revealed by 50 -year long observations along $137^{\circ} \mathrm{E}$. J Oceanogr. https://doi.org/10.1007/s1087 2-017-0416-2

Piecuch CG, Ponte RM, Little CM, Buckley MW, Fukumori I (2017) Mechanisms underlying recent decadal changes in subpolar North Atlantic Ocean heat content. J Geophys Res Oceans. https ://doi.org/10.1002/2017jc012845

Ponte RM, Vinogradova NT (2016) An assessment of basic processes controlling mean surface salinity over the global ocean. Geophys Res Lett. https://doi.org/10.1002/2016gl069857

Qu T, Song YT, Maes C (2014) Sea surface salinity and barrier layer variability in the equatorial Pacific as seen from Aquarius and Argo. J Geophys Res Oceans 119:15-29. https://doi. org/10.1002/2013JC009375

Rahmstorf S (2003) Thermohaline circulation: the current climate. Nature 421:699. https://doi.org/10.1038/421699a

Reul N, Fournier S, Boutin J et al (2014) Sea surface salinity observations from space with the SMOS satellite: a new means to monitor the marine branch of the water cycle. Surv Geophys 35:681-722. https://doi.org/10.1007/s10712-013-9244-0

Rhein M, Rintoul SR, Aoki S et al (2013) Observations: Ocean. In: Climate Change 2013: The Physical Science Basis. Contribution of Working Group I to the Fifth Assessment Report of the Intergovernmental Panel on Climate Change. Cambridge University Press, Cambridge and New York

Riser SC, Ren L, Wong A (2008) Salinity in Argo: a modern view of a changing Ocean. Oceanography 21:56-67. https://doi. org/10.5670/oceanog.2008.67

Riser SC, Freeland HJ, Roemmich D et al (2016) Fifteen years of ocean observations with the global Argo array. Nat Clim Change 6:145-153. https://doi.org/10.1038/nclimate2872

Roemmich D, Gilson J (2009) The 2004-2008 mean and annual cycle of temperature, salinity, and steric height in the global ocean from the Argo program. Prog Oceanogr 82:81-100. https://doi. org/10.1016/j.pocean.2009.03.004

Roemmich D, Morris M, Young WR, Donguy JR (1994) Fresh equatorial jets. J Phys Oceanogr 24:540-558. https://doi. org/10.1175/1520-0485(1994)024\%3c0540:FEJ\%3e2.0.CO;2

Roemmich D, Johnson GC, Riser SC et al (2009) The Argo program: observing the global ocean with profiling floats. Oceanography 22:34-43. https://doi.org/10.5670/oceanog.2009.36

Schanze JJ, Schmitt RW, Yu L (2010) The global oceanic freshwater cycle: a state-of-the-art quantification. J Mar Res 68:569-595. https://doi.org/10.1357/002224010794657164

Schmitt RW (2008) Salinity and the global water cycle. Oceanography 21:12-19. https://doi.org/10.5670/oceanog.2008.63 
Seager R, Henderson N (2013) Diagnostic computation of moisture budgets in the ERA-interim reanalysis with reference to analysis of CMIP-archived atmospheric model data. J Clim 26:78767901. https://doi.org/10.1175/jcli-d-13-00018.1

Seager R, Naik N, Vecchi GA (2010) Thermodynamic and dynamic mechanisms for large-scale changes in the hydrological cycle in response to global warming*. J Clim 23:4651-4668. https://doi. org/10.1175/2010JCLI3655.1

Sen PK (1968) Estimates of the regression coefficient based on Kendall's tau. J Am Stat Assoc 63:1379-1389. https://doi. org/10.1080/01621459.1968.10480934

Singh A, Delcroix T, Cravatte S (2011) Contrasting the flavors of El Niño-Southern Oscillation using sea surface salinity observations. J Geophys Res. https://doi.org/10.1029/2010jc006862

Skliris N, Marsh R, Josey SA, Good SA, Liu C, Allan RP (2014) Salinity changes in the World Ocean since 1950 in relation to changing surface freshwater fluxes. Clim Dyn 43:709-736. https://doi. org/10.1007/s00382-014-2131-7

Song L et al (2018) Tropical meridional overturning circulation observed by subsurface moorings in the western Pacific. Sci Rep 8:7632. https://doi.org/10.1038/s41598-018-26047-7

Terray L, Corre L, Cravatte S, Delcroix T, Reverdin G, Ribes A (2012) Near-surface salinity as nature's rain gauge to detect human influence on the tropical water cycle. J Clim 25:958-977. https://doi. org/10.1175/jcli-d-10-05025.1

Trenberth KE, Fasullo J, Smith L (2005) Trends and variability in column-integrated atmospheric water vapor. Clim Dyn 24:741-758. https://doi.org/10.1007/s00382-005-0017-4

Trenberth KE, Fasullo JT, Mackaro J (2011) Atmospheric moisture transports from ocean to land and global energy flows in reanalyses. J Clim 24:4907-4924. https://doi.org/10.1175/2011j cli4171.1

Trenberth KE, Fasullo JT, Branstator G, Phillips AS (2014) Seasonal aspects of the recent pause in surface warming. Nat Clim Change 4:911-916

Vinogradova NT, Ponte RM (2013) Clarifying the link between surface salinity and freshwater fluxes on monthly to interannual time scales. J Geophys Res Oceans 118:3190-3201. https://doi. org/10.1002/jgrc. 20200

Vinogradova NT, Ponte RM (2017) In search of fingerprints of the recent intensification of the ocean water cycle. J Clim. https:// doi.org/10.1175/jcli-d-16-0626.1

Wang J, Spall MA, Flierl GR, Malanotte-Rizzoli P (2012) A new mechanism for the generation of quasi-zonal jets in the ocean. Geophys Res Lett. https://doi.org/10.1029/2012g1051861

Wang C, Zhang L, Lee S (2013a) Response of freshwater flux and sea surface salinity to variability of the atlantic warm pool. J Clim 26:1249-1267. https://doi.org/10.1002/jgrc.20200

Wang J, Spall MA, Flierl GR, Malanotte-Rizzoli P (2013b) Nonlinear radiating instability of a barotropic eastern boundary current. J Phys Oceanogr 43:1439-1452. https://doi.org/10.1175/ JPO-D-12-0174.1

Wang Y, Wu C, Chao S (2016) Warming and weakening trends of the Kuroshio during 1993-2013. Geophys Res Lett 43:9200-9207. https://doi.org/10.1002/2016GL069432

Wang G, Cheng L, Boyer T, Li C (2017) Halosteric sea level changes during the Argo era. Water 9:484. https://doi.org/10.3390/w9070 484
Wang G, Cheng L, Abraham J, Li C (2018) Consensuses and discrepancies of basin-scale ocean heat content changes in different ocean analyses. Clim Dyn 50:2471-2487. https://doi.org/10.1007/s0038 2-017-3751-5

Wong AP, Bindoff NL, Church JA (1999) Large-scale freshening of intermediate waters in the Pacific and Indian oceans. Nature 400:440. https://doi.org/10.1038/22733

Wu L et al (2012) Enhanced warming over the global subtropical western boundary currents. Nat Clim Change 2:161. https://doi. org/10.1038/nclimate1353

Wu C, Wang Y, Lin Y, Chao S (2017) Intrusion of the Kuroshio into the South and East China Seas. Sci Rep 7:7895. https://doi. org/10.1038/s41598-017-08206-4

Wunsch C, Hemibach P, Ponte RM, Fukumori I (2009) The global general circulation of the ocean estimated by the ECCO-Consortium. Oceanography 22:88-103. https://doi.org/10.5670/ocean og.2009.41

Xie S-P, Philander SGH (1994) A coupled ocean-atmosphere model of relevance to the ITCZ in the eastern Pacific. Tellus A 46:340 350. https://doi.org/10.1034/j.1600-0870.1994.t01-1-00001.x

Yan Y, Xu D, Yu K, Qi Y (2017) Propagation of the subsurface freshening water and its major source in the northwestern Pacific. J Geophys Res Oceans. https://doi.org/10.1002/2017jc013033

Yu L (2011) A global relationship between the ocean water cycle and near-surface salinity. J Geophys Res. https://doi. org/10.1029/2010jc006937

Yu L, Weller RA (2007) Objectively analyzed air-sea heat fluxes for the global ice-free oceans (1981-2005). Bull Am Meteorol Soc 88:527-540. https://doi.org/10.1175/BAMS-88-4-527

Yu L, Jin X, Josey SA, Lee T, Kumar A, Wen C, Xue Y (2017) The global ocean water cycle in atmospheric reanalysis, satellite, and Ocean salinity. J Clim 30:3829-3852. https://doi.org/10.1175/ jcli-d-16-0479.1

Zhang L (2016) The roles of external forcing and natural variability in global warming hiatuses. Clim Dyn 47:3157-3169. https://doi. org/10.1007/s00382-016-3018-6

Zhang Y, Feng M, Du Y, Phillips HE, Bindoff NL, McPhaden MJ (2018) Strengthened Indonesian Throughflow drives decadal warming in the Southern Indian Ocean. Geophys Res Lett. https ://doi.org/10.1029/2018g1078265

Zheng F, Zhang R (2015) Interannually varying salinity effects on ENSO in the tropical pacific: a diagnostic analysis from Argo. Ocean Dyn 65:691-705. https://doi.org/10.1007/s1023 6-015-0829-7

Zheng F, Zhang R, Zhu J (2014) Effects of interannual salinity variability on the barrier layer in the western-central equatorial Pacific: a diagnostic analysis from Argo. Adv Atmos Sci 31:532-542. https ://doi.org/10.1007/s00376-013-3061-8

Zhu J, Huang B, Zhang R et al (2014) Salinity anomaly as a trigger for ENSO events. Sci Rep 4:6821. https://doi.org/10.1038/srep06821

Publisher's Note Springer Nature remains neutral with regard to jurisdictional claims in published maps and institutional affiliations. 